\title{
THE COMPOSITION AND RECONSTRUCTION OF THE SOURCE AREA FOR THE LATE PRECAMBRIAN TERRIGENOUS ROCKS OF THE OSELKOVAYA SERIES (BIRYUSA PRISAYANIE)
}

\author{
Z. L. Motova, T. V. Donskaya, D. P. Gladkochub \\ Institute of the Earth's Crust, Siberian Branch of RAS, Irkutsk, Russia
}

\begin{abstract}
We present results from petrographic and lithogeochemical studies of the Late Precambrian terrigenous rocks (sandstones, gravelites, and aleuritic sandstones) from the Oselkovaya series of Prisayanie. The studies were conducted to reconstruct the primary composition of the rocks in the source area. It has been found that the rocks in the lower part of the cross-section of this series (Marninskaya suite, and the lower part of the Udinskaya suites) are represented by more coarse-grained terrigenous rocks (gravelites, and sandstones) as compared to the upper part of the cross-section (the upper part of the Udinskaya suite, and the Aisinskaya suite) with sandstones and aleuritic sandstones. Gravelites and sandstones from the lower part of the Oselkovaya series show indicators of epigenetic changes that are less intensively expressed in the rocks from the upper part of the cross-section. The upper and lower parts of the Oselkovaya series are significantly different in terms of lithogeochemistry. The lower rocks show quite low contents of $\mathrm{Na}_{2} \mathrm{O}$ and ratios $\mathrm{K}_{2} \mathrm{O} / \mathrm{Na}_{2} \mathrm{O}$ ranging between 10 and 75 . In the terrigenous sediments of the upper part, values of $\mathrm{K}_{2} \mathrm{O} / \mathrm{Na}_{2} \mathrm{O}$ do not exceed 1-2. Sandstones and gravelites in the lower part of the Oselkovaya series are characterized by reduced concentrations of radioactive, rare-earth, and highly charged elements, as well as lower concentrations of $\mathrm{Ni}$ and Co relative to concentrations of these elements in sandstones and aleuritic sandstones of the Oselkovaya series. The petrographic and lithogeochemical characteristics of the terrigenous sediments of the lower and upper parts of the Oselkovaya series suggest different sources of the denudation of these rocks into the sedimentation basin. It is suggested that acid rocks were the denudation source of the terrigenous rocks in the lower part of the series, and the sandstones and aleuritic sandstones in the upper part of the series were sourced from rocks of a mixed (acid-base) composition. The composition of the rocks in the source area was reconstructed, and the published ages of detrital zircons from the sandstones of the upper and lower parts of the Oselkovaya series were taken into account. The reconstruction suggests that the lower part of the Oselkovaya series resulted from the destruction of the basement rocks in the Siberian craton. The upper part of the Oselkovaya series seems to have formed in the basin, wherein the denudation took place from the orogen formed as a result of the accretion of micro-continents and island arcs of the Paleo-Asian Ocean to the south-western margin of the Siberian craton.
\end{abstract}

Key words: terrigenous rock; epigenesis; lithogeochemistry; petrography; Late Precambrian; Biryusa Prisayanie; Siberian craton

Recommended by E.V. Sklyarov

For citation: Motova Z.L., Donskaya T.V., Gladkochub D.P. 2016. The composition and reconstruction of the source area for the Late Precambrian terrigenous rocks of the Oselkovaya series (Biryusa Prisayanie). Geodynamics \& Tectonophysics 7 (4), 625-649. doi:10.5800/GT-2016-7-4-0225.

Для цитирования: Мотова З.Л., Донская Т.В., Гладкочуб Д.П. Вещественный состав и реконструкция источников сноса позднедокембрийских терригенных пород оселковой серии (Бирюсинское Присаянье) // Геодинамика и тектонофизика. 2016. Т. 7. № 4. С. 625-649. doi:10.5800/GT-2016-7-40225. 


\title{
ВЕЩЕСТВЕННЫЙ СОСТАВ И РЕКОНСТРУКЦИЯ ИСТОЧНИКОВ СНОСА ПОЗДНЕДОКЕМБРИЙСКИХ ТЕРРИГЕННЫХ ПОРОД ОСЕЛКОВОЙ СЕРИИ (БИРЮСИНСКОЕ ПРИСАЯНЬЕ)
}

\author{
3. Л. Мотова, Т. В. Донская, Д. П. Гладкочуб \\ Институт земной коры СО РАН, Иркутск, Россия
}

\begin{abstract}
Аннотация: В работе представлены результаты петрографических и литогеохимических исследований позднедокембрийских терригенных пород (песчаников, гравелитов и алевропесчаников) оселковой серии Присаянья с целью реконструкции первичного состава пород в области источника сноса обломочного материала. В результате проведенных исследований было установлено, что породы нижней части разреза серии (марнинская и нижняя часть удинской свиты) характеризуются более грубозернистым составом обломочных пород (гравелиты и песчаники) относительно пород верхней части разреза серии (верхняя часть удинской и айсинская свита), которые представлены песчаниками и алевропесчаниками. В гравелитах и песчаниках нижней части оселковой серии диагностируются признаки эпигенетических преобразований, которые менее интенсивно выражены в породах верхней части разреза. Для верхней и нижней части оселковой серии отмечаются существенные литогеохимические отличия. Породы низов серии обнаруживают весьма низкие содержания $\mathrm{Na}_{2} \mathrm{O}$, значение $\mathrm{K}_{2} \mathrm{O} / \mathrm{Na}_{2} \mathrm{O}$ в них изменяется от 10 до 75. Для терригенных отложений верхней части серии величины $\mathrm{K}_{2} \mathrm{O} / \mathrm{Na}_{2} \mathrm{O}$ не превышают 1-2. Песчаники и гравелиты нижней части оселковой серии характеризуются пониженными концентрациями радиоактивных, редкоземельных, высокозарядных элементов, а также $\mathrm{Ni}$ и Со относительно концентраций этих элементов в песчаниках и алевропесчаниках верхней части оселковой серии. Совокупность петрографических и литогеохимических характеристик терригенных отложений нижней и верхней части оселковой серии свидетельствует о различных источниках сноса в бассейн седиментации этих пород. Для терригенных пород нижней части серии в качестве основного источника сноса были приняты породы кислого состава, а для песчаников и алевропесчаников верхней части серии предполагается, что источник сноса мог иметь смешанный (кислый - основной) состав. Проведенная реконструкция состава пород в области источников сноса с учетом опубликованных ранее данных о возрасте детритовых цирконов из песчаников верхней и нижней части оселковой серии позволяет предположить, что низы оселковой серии образовались за счет разрушения пород фундамента Сибирского кратона. Верхняя часть оселковой серии могла быть образована в бассейне, снос в который осуществлялся с орогена, сформировавшегося в результате аккреции микроконтинентов и островных дуг Палеоазиатского океана к юго-западной окраине Сибирского кратона.
\end{abstract}

Ключевые слова: терригенные породы; эпигенез; литогеохимия; петрография; поздний докембрий; Бирюсинское Присаянье; Сибирский кратон

\section{1. ВВЕДЕНИЕ}

Позднедокембрийские осадочные породы широко развиты вдоль южной окраины Сибирского кратона. В Присаянье они представлены осадочными отложениями карагасской и оселковой серий. Оселковая серия, для которой принимается вендский возраст [Sovetov, Komlev, 2005; Letnikova et al., 2013; Sovetov et al., 2015], подразделяется на три свиты: марнинскую, удинскую и айсинскую. Породы оселковой серии исследовались на протяжении многих лет [Dolnik, Vorontsov, 1972; Shenfil', 1991; Sovetov, Komlev, 2005; Sovetov et al., 2015; Sklyarov, 2006; Stanevich et al., 2007; Metelkin et al., 2010; Letnikova et al., 2013; и дp.], при этом наибольшее внимание уделялось седиментологическому анализу и литостратиграфическим корреляциям, в меньшей степени проводилось изучение изотопно-геохи- мических и петрофизических свойств этих пород. В единственной опубликованной работе по геохимии пород оселковой серии [Letnikova et al., 2013] авторами был сделан вывод, что терригенные породы всех свит оселковой серии имеют сходные изотопные и геохимические характеристики. Однако данные по возрасту детритовых цирконов из пород удинской и айсинской свит указывают на то, что имеются кардинальные отличия в возрастных спектрах цирконов из терригенных пород разных частей разреза оселковой серии [Letnikova et al., 2013; Sovetov et al., 2015; Motova, 2016]. Результаты исследования детритовых цирконов показали необходимость детального петрографического и литогеохимического изучения пород разных свит оселковой серии по отдельности, чтобы выявить возможные изменения состава пород по разрезу, которые, в свою очередь, свидетельствуют об 


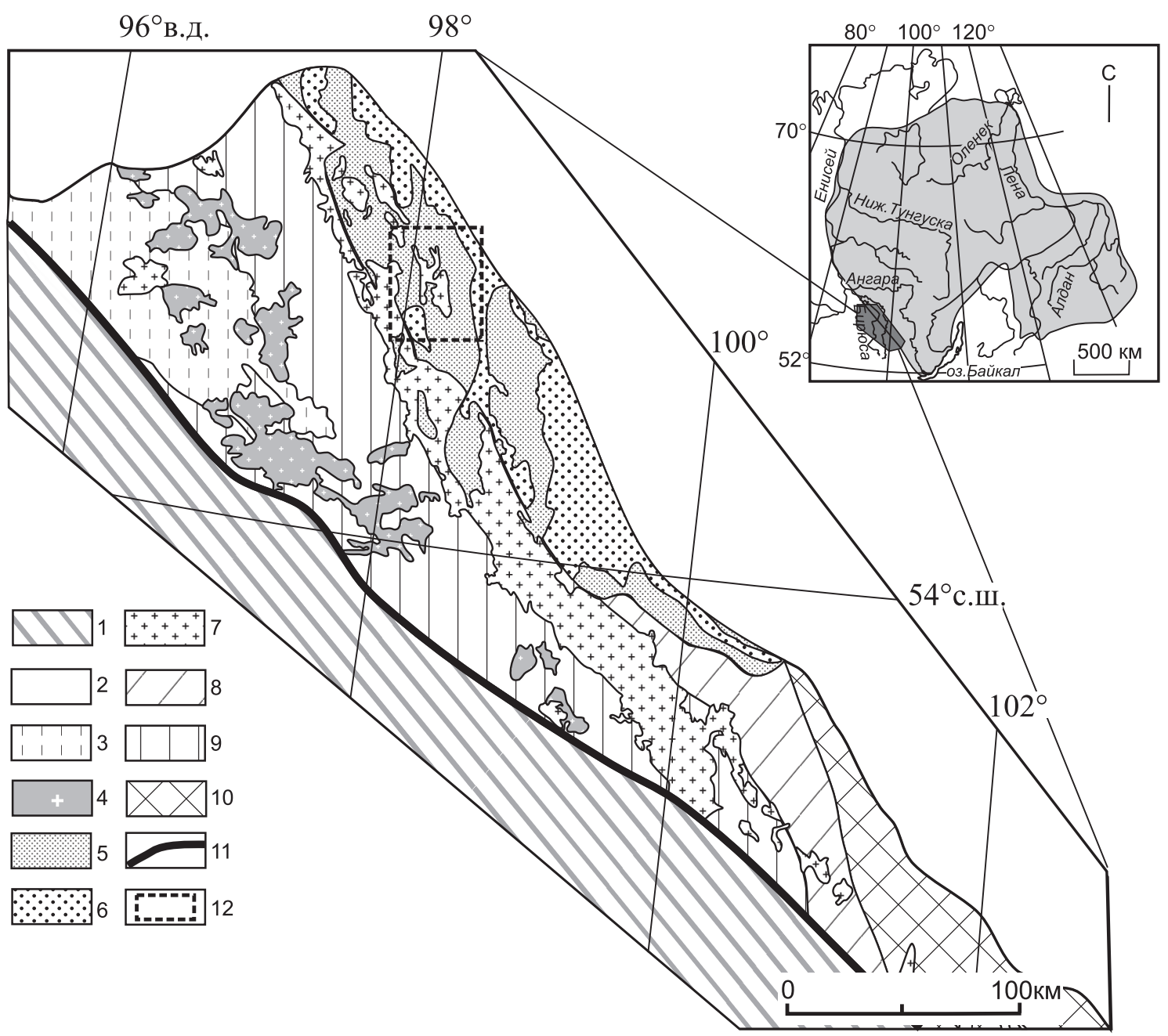

Рис. 1. Геологическая схема БирюсинскогоПрисаянья (по [Galimova et al., 2011]).

1 - Центрально-Азиатский складчатый пояс; 2 - фанерозойские образования чехла Сибирской платформы; 3 - девонские вулканогенно-осадочные породы наложенных впадин; 4 - палеозойские гранитоиды; 5 - осадочные отложения оселковой серии; 6 осадочные отложения карагасской серии; 7 - раннепротерозойские постколлизионные гранитоиды; 8 - раннепротерозойские образования Урикско-Ийского блока фундамента Сибирского кратона; 9 - раннепротерозойские - архейские образования Бирюсинского блока фундамента Сибирского кратона; 10 - архейские образования Шарыжалгайского выступа фундамента Сибирского кратона; 11 - Главный Саянский разлом; 12 - участок детальных работ. На врезке показаны контуры Сибирской платформы и район исследований.

Fig. 1. Geological scheme of the Biryusa Prisayanie (from [Galimova et al., 2011]).

1 - Central Asian folded belt; 2 - Phanerozoic formations in the shield of the Siberian platform; 3 - Devonian volcano-sedimentary rocks of superimposed basins; 4 - Paleozoic granitoids; 5 - sedimentary deposits of the Oselkovaya series; 6 - sedimentary deposits of the Karagass series; 7 - Early Proterozoic post-collision granitoids; 8 - Early Proterozoic formations of the Urik-Yi block in the base of the Siberian craton; 9 - Early Proterozoic - Archean formations of the Biryusa block in the base of the Siberian craton; 10 - Archean formations of the Sharyzhalgai edge in the base of the Siberian craton; 11 - Main Sayan Fault; 12 - site studied in detail. The inset shows the contours of the Siberian platform and the study area.

изменении источников обломочного материала, поступающего в бассейн седиментации.

Задача данной работы заключалась в детальном петрографическом и литогеохимическом исследовании терригенных пород марнинской, удинской и айсинской свит оселковой серии, а также в интерпретации результатов геохимических исследований с целью реконструкции состава пород в области сноса обломочного материала.

\section{2. ГЕОЛОГИЧЕСКОЕ СТРОЕНИЕ БИРЮСИНСКОГО ПРИСАЯНЬЯ}

Позднерифейские и вендские осадочные отложения широко распространены в пределах Бирюсинского блока Присаянского краевого выступа южной окраины Сибирского кратона (рис. 1). Бирюсинский блок протягивается в северо-западном направлении на 350 км от бассейна р. Ока до 
бассейна р. Агул и далее, достигая максимальной ширины 80 км. На юго-востоке Бирюсинский блок примыкает к Урикско-Ийскому грабену, а на югозападе ограничивается Главным Саянским разломом. В северо-западной части породы Бирюсинского блока перекрыты среднепалеозойскими отложениями Рыбинской впадины. В целом, Бирюсинский блок представляет собой гетерогенную структуру, состоящую из позднеархейских пород (хайламинская и монкресская серии) и раннепротерозойских отложений (елашская и неройская серии) [Sklyarov, 2006]. В пределах Бирюсинского блока широко распространены раннепротерозойские неметаморфизованные гранитоиды саянского комплекса, которые прослеживаются вдоль зоны его сочленения с другими блоками Сибирского кратона. Данные гранитоиды прорывают позднеархейские образования хайламинской и монкресской серий, а также раннепротерозойские образования елашской (сублукской) серии и со значительным несогласием перекрываются позднерифейскими и вендскими терригенными породами карагасской и оселковой серий [Sklyarov, 2006].

Терригенные отложения оселковой серии, широко развитые на территории Бирюсинского Присаянья, с эрозионным контактом залегают на отложениях карагасской серии и не контактируют с породами фундамента Сибирского кратона. Как уже было отмечено выше, в составе оселковой серии выделяется три свиты: марнинская, удинская и айсинская (рис. 2) [Decisions..., 1983; Galimova et al., 2011].

Марнинская свита, с горизонтом валунно-галечных конгломератов в основании, сложена преимущественно серыми разнозернистыми песчаниками и гравелитами с линзами конгломератов и доломитов. В верхах разреза свиты отмечается монотонная толща тонкозернистых песчаников с маломощными прослоями алевролитов, гравелитов и доломитов. Мощность отложений марнинской свиты изменяется от 400 до 660 м.

Удинская свита с размывом залегает на породах нижележащей марнинской свиты и в основании сложена серыми гравелитами и крупнозернистыми песчаниками. Выше по разрезу залегают тонкозернистые алевролиты и строматолитовые известняки. Далее следует мощная однородная по составу толща полевошпат-кварцевых разнозернистых песчаников с прослоями алевролитов. Верхняя часть свиты представлена ритмичным чередованием тонкозернистых розовых песчаников, алевролитов и аргиллитов. Суммарная мощность удинской свиты от 200 до 550 м.

Айсинская свита согласно залегает на отложениях удинской свиты. В основании свиты залегают крупнозернистые песчаники с гравийными зерна-

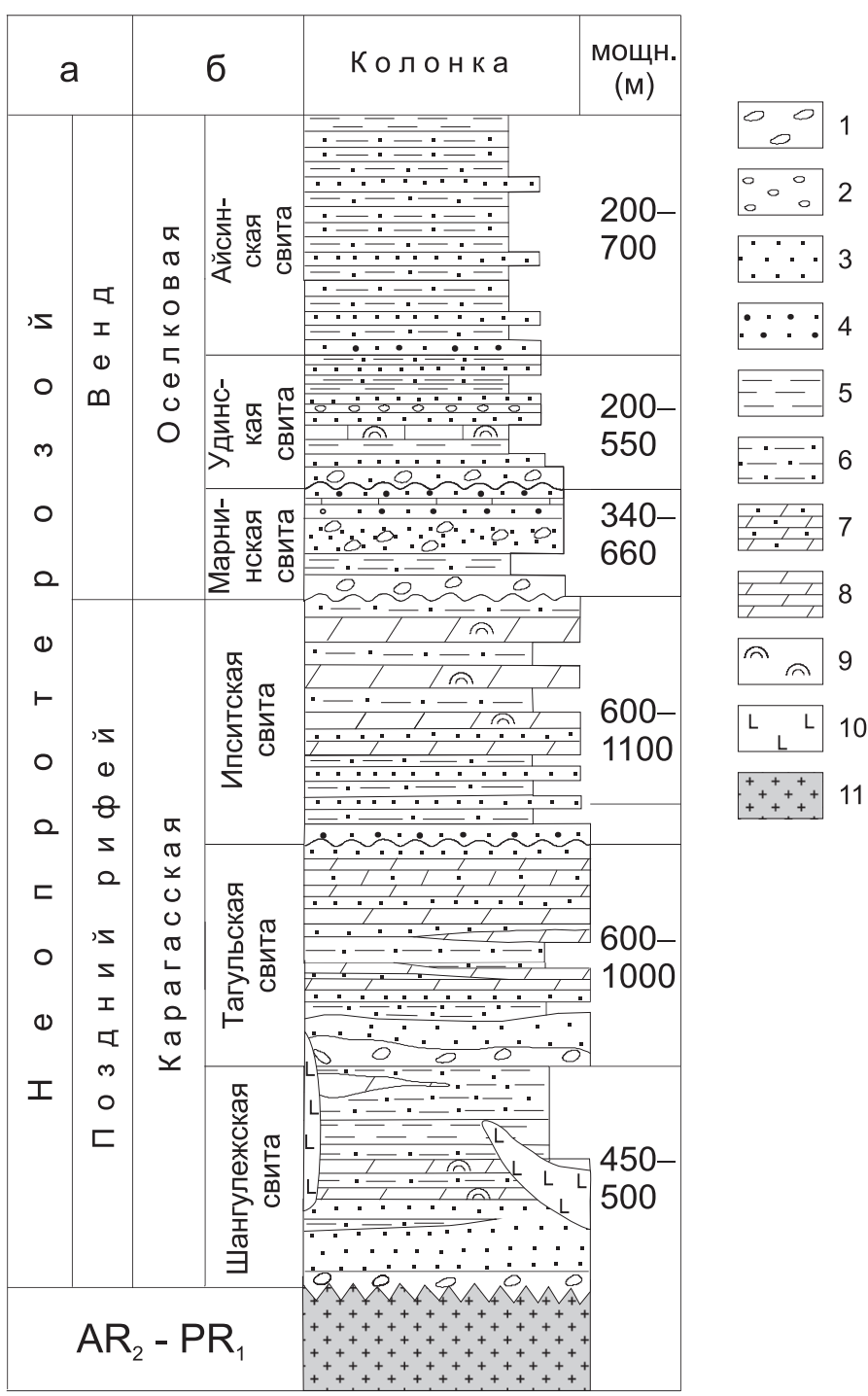

Рис. 2. Литологическая колонка докембрийских образований Бирюсинского Присаянья (модифицирована после [Decisions..., 1983; Bragin, 1985]).

а - общая хроностратиграфическая шкала; б - серии и свиты. 1 - конгломераты; 2 - мелкогалечные конгломераты и гравелиты; 3 - песчаники; 4 - кремнистые алевролиты и песчаники; 5 - аргиллиты; 6 - алевролиты; 7 - песчанистые доломиты; 8 - доломиты; 9 - строматолиты и микрофитолиты; 10 - долериты и габбро-долериты; 11 - позднеархейскийраннепротерозойский фундамент Сибирского кратона.

Fig. 2. The lithological column of the Precambrian formations in the Biryusa Prisayanie (modified after [Decisions..., 1983; Bragin, 1985]).

a - general chronostratigraphic scale; b - series and suites. 1 conglomerate; 2 - pebbly conglomerate and gravelite; 3 - sandstone; 4 - siliceous siltstone and sandstone; 5 - argillite; 6 - aleurolite; 7 - sandy dolomite; 8 - dolomite; 9 - stromatolite and microphytolite; 10 - dolerite and gabbro-dolerite; 11 - Late Archean - Early Proterozoic base of the Siberian craton.

ми кварца, выше по разрезу наблюдается чередование красноцветных алевролитов, аргиллитов и тонкозернистых песчаников. Верхняя часть свиты 
сложена преимущественно полимиктовыми песчаниками с маломощными прослоями алевролитов и аргиллитов. Мощность отложений айсинской свиты варьируется от 200 до 700 м.

Согласно современным представлениям [Sovetov, Komlev, 2005; Sklyarov, 2006; Metelkin et al., 2010; Letnikova et al., 2013; Sovetov et al., 2015], накопление отложений оселковой серии происходило в пределах обширного окраинно-континентального шельфа.

Возраст оселковой серии изначально принимался как позднерифейский [Bragin, 1985; Shenfil', 1991; Dolnik, 2000; Khomentovskii, 2002; и дp.]. Позднее, в результате межрегиональных стратиграфических корреляций, был сделан вывод о вендском возрасте отложений оселковой серии [Sovetov, Kom$l e v, 2005]$. Датирование детритовых цирконов из отложений оселковой серии, а именно из отложений нижней и верхней части удинской свиты и базальных горизонтов айсинской свиты, позволило выделить два основных типа возрастных спектров для исследованных пород [Letnikova et al., 2013; Sovetov et al., 2015; Motova, 2016]. В частности, отложения нижней части удинской свиты характеризуются наличием исключительно архей-раннепротерозойских цирконов, тогда как для верхней части удинской свиты и базальных слоев айсинской свиты наряду с архей-раннепротерозойскими отмечается обилие детритовых цирконов позднерифейского возраста.

Для петрографических и литогеохимических исследований нами проведено опробование терригенных отложений всех трех свит оселковой серии. Песчаники и гравелиты марнинской свиты были изучены в коренных выходах на устье р. Нерса левого притока р. Бирюса (рис. 3, т.н. 1). Песчаники и алевропесчаники удинской свиты были опробованы в трех разрезах: отложения нижней подсвиты удинской свиты были опробованы в междуречье рек Уда - Бирюса (т.н. 2), а также в междуречье рек Бирюса - Нерса (т.н. 4); породы верхней подсвиты удинской свиты изучены в приустьевой части p. Нерса (правый борт р. Бирюса) (т.н. 3). Пробы алевропесчаников айсинской свиты были отобраны в двух разрезах: в междуречье рек Бирюса - Тагул (т.н. 5), а также в коренных выходах по левому борту р. Тагул (левый приток р. Бирюса) (т.н. 6).

\section{3. ПЕТРОГРАФИЧЕСКАЯ ХАРАКТЕРИСТИКА}

Петрографическая характеристика терригенных отложений оселковой серии приведена на основании исследований более 30 образцов гравелитов, песчаников и алевропесчаников. В соответствии с классификациями песчаников по Н.В. Логвиненко
[Logvinenko, 1974] и Ф.Дж. Петтиджону с соавторами [Pettijohn, 1975], все исследуемые образцы относятся к группе аркозов. На классификационной диаграмме Н.В. Логвиненко (рис. 4, a) фигуративные точки исследуемых пород расположились в поле аркозов и кварц-полевошпатовых песчаников, на диаграмме Ф.Дж. Петтиджона с соавторами (рис. 4, б) - в поле аркозов и субаркозов.

Отложения марнинской свиты представлены песчаниками и гравелитами, которые сложены плохо отсортированным полуокатанным (20 \%) и неокатанным (80 \%) обломочным материалом (рис. 5, a, б). Размер зерен в песчаниках изменяется от 0.1-0.3 до 1.0 мм, для них характерна псаммитовая структура и массивная текстура. Гравелиты сложены преимущественно обломочными зернами размером от 1.3 до 7.0 мм, в подчиненном количестве отмечаются зерна от 0.6 до 1.0 мм. Для гравелитов характерна псефо-псаммитовая структура и пятнистая текстура. Цемент контактовый, регенерационный. В составе обломочного материала песчаников и гравелитов марнинской свиты преобладают кварц (68-70 \%) и калиевые полевые шпаты (5-15 \%). Второстепенные минералы - магнетит, биотит и мусковит. Акцессорные минералы: турмалин, сфен-лейкоксен и циркон. Содержание обломков пород, которые представлены гранитоидами, кварцитами и кислыми эффузивами, варьируется от 1 до 5 \% в песчаниках и от 6 до $9 \%$ в гравелитах. Вторичные изменения выражены регенерацией обломочных зерен кварца, пелитизацией калиевых полевых шпатов с образованием глинистогидрослюдистого агрегата (иллит-серицит-гидромусковит), а также гребневидным обрастанием обломочных зерен калиевых полевых шпатов аутигенным калиевым полевым шпатом. Повсеместно отмечается хлоритизация биотита и интенсивное развитие гидроокислов железа, которые, скорее всего, образовались на стадии эпигенеза.

Породы нижней подсвиты удинской свиты представлены песчаниками и гравелитами, сложенными плохо отсортированными полуокатанными (22 \%) и неокатанными (78 \%) обломками (рис. 5, в, 2). Размер обломочных зерен в песчаниках изменяется от 0.1 до 0.7 мм; структура пород псаммитовая, текстура - массивная. Размер обломочных зерен в гравелитах 1.5-6.8 мм, редко отмечаются зерна размером от 0.3 до 0.6 мм. Структура пород псефо-псаммитовая, текстура пятнистая. Цемент контактовый, контактово-поровый. В минеральном составе песчаников и гравелитов преобладают кварц (65-72 \%) и калиевые полевые шпаты (15-18 \%). Второстепенные минералы: магнетит, биотит, мусковит. Акцессорные минералы: апатит, турмалин, сфен-лейкоксен и циркон. Обломки пород, количество которых в песчаниках варьируется 


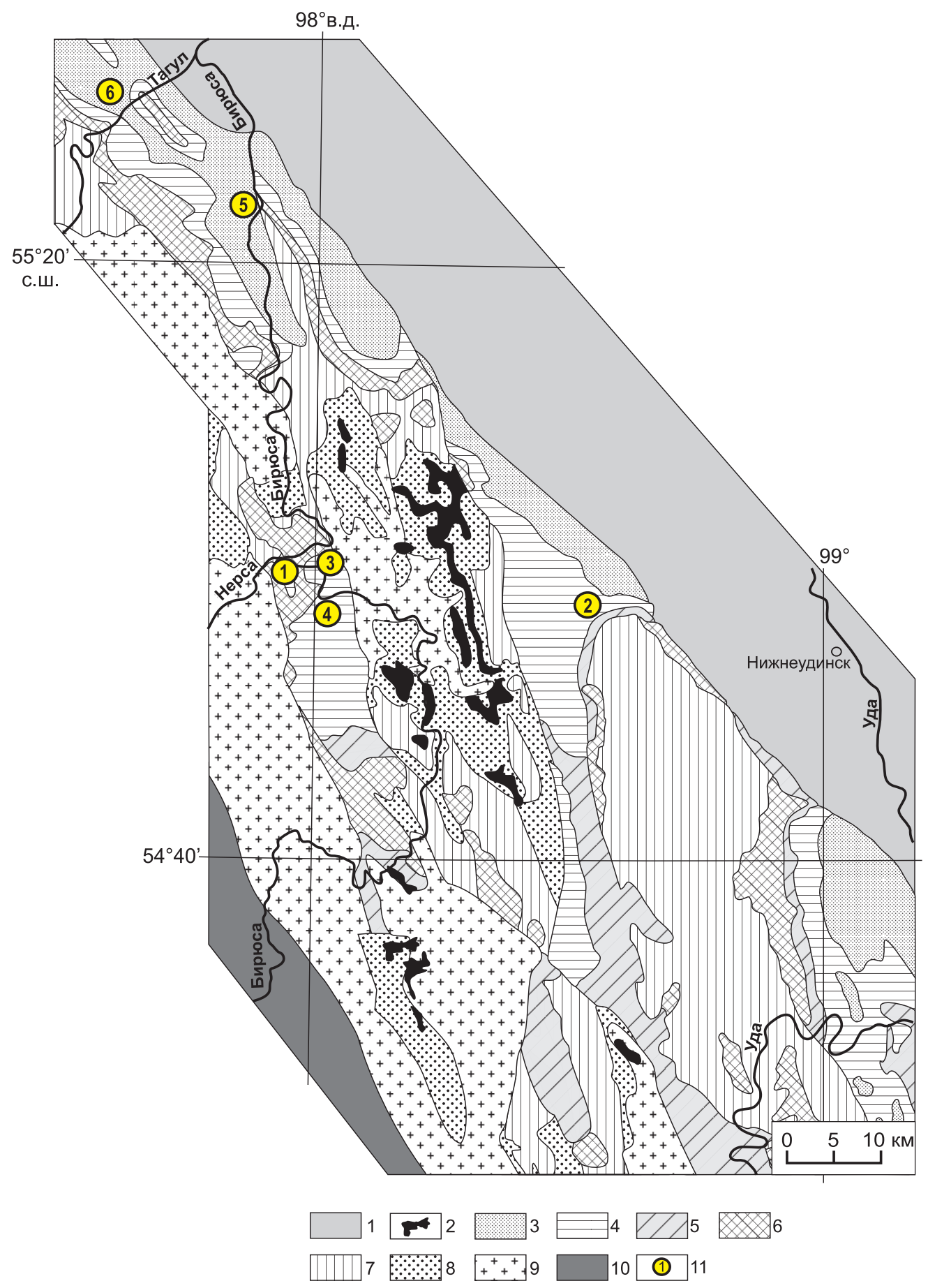

Рис. 3. Геологическая карта участка детальных работ (по [Galimova et al., 2011]).

1 - фанерозойские образования чехла Сибирской платформы; 2 - дайки и силлы долеритов и габбро-долеритов; 3-5 - оселковая серия: 3 - песчаники, алевролиты и аргиллиты айсинской свиты, 4 - песчаники, алевролиты, аргиллиты и гравеллиты удинской свиты, 5 - алевролиты, песчаники, известняки и доломиты марнинской свиты; 6-8 - карагасская серия: 6 - алевролиты, песчаники и доломиты ипситской свиты, 7 - песчаники, аргиллиты, алевролиты и доломиты тагульской свиты, 8 - конгломераты, песчаники, алевролиты и доломиты шангулежской свиты; 9 - раннепротерозойские гранитоиды саянского комплекса; 10 - раннепротерозойские - позднеархейские образования Бирюсинского блока фундамента Сибирского кратона; 11 - места отбора проб для исследований и их номера (табл. 1).

Fig. 3. Geological map of the site studied in detail (from [Galimova et al., 2011]).

1 - Phanerozoic formations in the shield of the Siberian platform; 2 - dykes and sills of dolerite and gabbro-dolerite; 3-5 - 0selkovaya series: 3 - sandstone, aleurolite, and argillite of the Aisinskaya suite, 4 - sandstone, aleurolite, argillite, and gravellite of the Udinskaya suite, 5 - aluerolite, sandstone, limestone, and dolomite of the Marninskay suite; 6-8 - Karagass series: 6 - aleutolite, sandstone, and dolomite of the Ipsitskaya suites, 7 - sandstone, argillite, aleurolite, and dolomite of the Tagulskaya suite, 8 - conglomerate, sandstone, aleurolite, and dolomite of the Shangulezhskaya suite; 9 - Early Proterozoic granitoid of the Sayansky complex; 10 - Early Proterozoic - Late Archean formations of the Biryusa block in the base of the Siberian craton; 11 - sampling locations and their numbers (Table 1). 

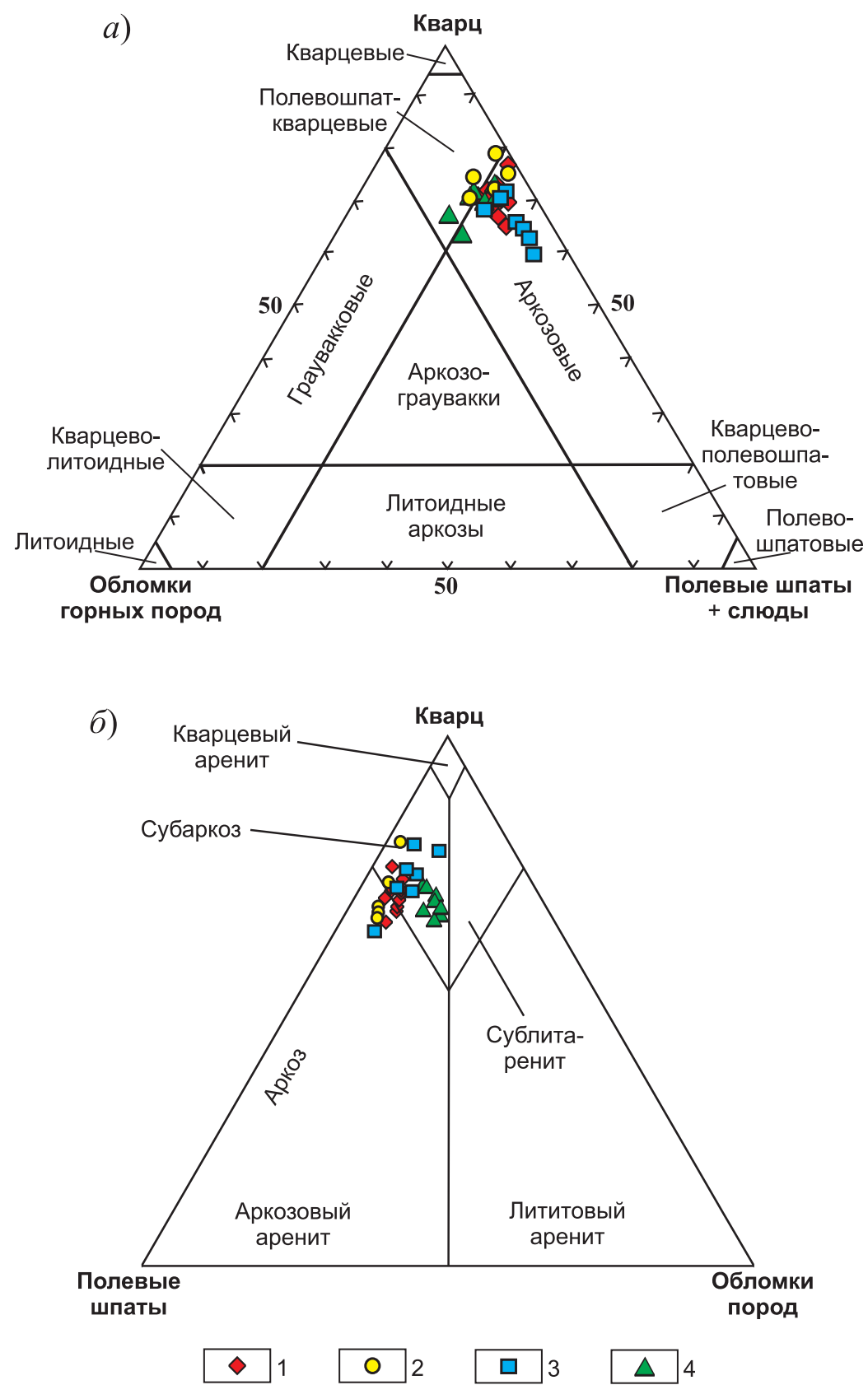

Рис. 4. Классификация песчаных и алевритовых пород оселковой серии: $a$ - по Н.В. Логвиненко [Logvinenko, 1974]; 6 - по Ф.Дж. Петтиджону [Pettijohn, 1975].

1 - марнинская свита; 2 - нижняя подсвита удинской свиты; 3 - верхняя подсвита удинской свиты; 4 - айсинская свита.

Fig. 4. Classification of sandy and aleuritic rocks of the Oselkovaya series: $a$ - according to [Logvinenko, 1974]; 6 - according to [Pettijohn, 1975].

1 - Marninskaya suite; 2 - lower part of Udinskaya suite; 3 - upper part of Udinskaya suite; 4 - Aisinskaya suite.

от 1 до 5 \%, в гравелитах - от 8 до $9 \%$, представлены гранитоидами, кварцитами и кислыми эффузивами. Вторичные изменения выражены пелитизацией калиевых полевых шпатов с образованием глинисто-слюдистого агрегата, изредка отмечаются регенерированные обломочные зерна кварца.

В разрезах верхней части удинской свиты наблюдаются песчаники и алевропесчаники, сложен- ные полуокатанными (50\%), окатанными (5\%) и неокатанными (45 \%) обломками плохой и средней степени сортировки (рис. 5, $\partial, e$ ). Микрослоистую текстуру песчаников и алевропесчаников верхней подсвиты удинской свиты обусловливают однонаправленно-ориентированные чешуйки слюды (мусковит и биотит). Размер обломочных зерен в песчаниках варьируется от 0.3 до 0.5 мм, для них 

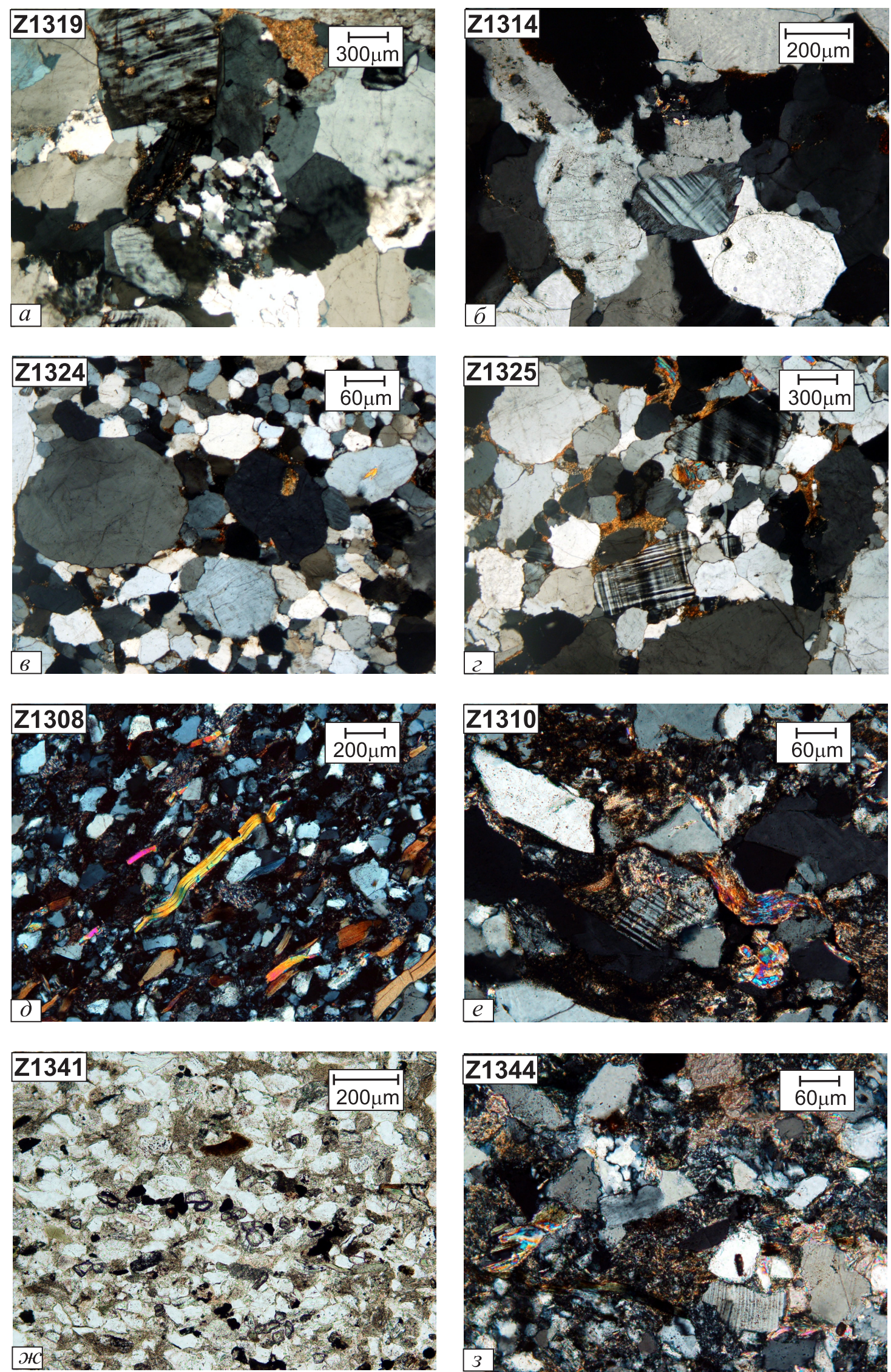

Рис. 5. Микрофотографии шлифов терригенных пород оселковой серии: $a$, 6 - марнинская свита; 8 , 2 - нижняя часть удинской свиты; $\partial, e-$ верхняя часть удинской свиты; ж, з - айсинская свита.

Fig. 5. Photomicrographs of the terrigenous rocks of the Oselkovaya series: $a$, $\sigma$ - Marninskaya suite; $8, z$ - lower part of Udinskaya suite; $\partial, e$ - upper part of Udinskaya suite;, 3 - Aisinskaya suite. 
характерна псаммитовая структура. В составе алевропесчаников преобладают обломочные зерна размером от 0.06 до 0.30 мм, реже отмечаются зерна от 0.3 до 0.6 мм. Цемент контактово-поровый, глинистый. В минеральном составе этих песчаников и алевропесчаников преобладают кварц (57-70 \%) и полевые шпаты (плагиоклаз и калиевый полевой шпат) (10-28 \%). Второстепенные минералы: мусковит, биотит и магнетит. Акцессорные минералы: циркон, турмалин, сфен-лейкоксен, апатит. Среди обломков пород (5-15 \%) отмечаются гранитоиды, кварциты и алевролиты. Вторичные изменения в породах верхней подсвиты удинской свиты проявлены слабой пелитизацией калиевых полевых шпатов с образованием иллита и серицита, а также интенсивным развитием гидроокислов железа.

Отложения айсинской свиты представлены алевропесчаниками, сложенными обломочным материалом различной степени окатанности и сортировки, размер частиц от 0.03-0.06 до 0.1-0.2 мм (рис. 5, ж, 3). Для них характерна алевропсаммитовая структура и микрослоистая текстура, которую обусловливают кальцитсодержащие слои, чередующиеся с микрослоями, обогащенными минералами тяжелой фракции (циркон, сфен) (рис. 5, ж). Цемент базально-поровый, глинисто-карбонатный. В составе пород преобладают кварц (60-70 \%) и полевые шпаты (плагиоклаз и калиевый полевой шпат) (16-20 \%). Второстепенные минералы: мусковит, биотит, магнетит и ильменит. Акцессорные минералы: турмалин, циркон, сфен-лейкоксен, эпидот. Обломки пород (5-15 \%) представлены гранитоидами, кварцитами, аргиллитами, а также эффузивами основного и кислого состава. Вторичные изменения выражены слабой пелитизацией калиевых полевых шпатов, а также хлоритизацией биотита.

\section{4. ЛИТОГЕОХИМИЧЕСКАЯ ХАРАКТЕРИСТИКА}

Аналитические работы были выполнены с использованием оборудования Центра коллективного пользования «Геодинамика и геохронология» ИЗК СО РАН (г. Иркутск). Определение основных петрогенных оксидов проведено методом силикатного анализа по методике [Revenko, 2014] (аналитики Н.Н. Ухова, Н.Ю. Царева). Пределы обнаружения петрогенных оксидов составляют не более 0.05 \%. Определение Co, Ni и Sc произведено методом спектрального анализа (аналитики В.В. Щербань, Л.В. Воротынова, А.В. Наумова) по стандартной методике на модернизированном атомноэмиссионном спектрометре ДФС-13. Пределы обнаружения Co, Ni и Sc составили не более 2 г/т.
Определение содержаний редких и редкоземельных элементов выполнялось методом ICP-MS в ОПЦКП «Ультрамикроанализ» Лимнологического института СО РАН на квадрупольном масс-спектрометре Agilent 7500ce (Agilent Technologies Inc., США) (аналитик С.В. Пантеева) по методике [Panteeva et al., 2003]. Концентрации элементов рассчитаны относительно международных стандартов AGV-2, BCR-2, JG-2, G-2, GSP-2. Ошибка определений редких и редкоземельных элементов методом ICP-MS coставляет не более $5 \%$.

\section{1. ПЕТРОГЕННЫЕ ЭЛЕМЕНТЫ}

Содержания петрогенных оксидов в изученных породах оселковой серии приведены в таблице 1. Терригенные породы низов оселковой серии (марнинская и нижняя часть удинской свиты) имеют отличные от верхов этой же серии (верхняя часть удинской и айсинская свита) петрохимические характеристики. Так, на классификационной диаграмме $\log \left(\mathrm{Na}_{2} \mathrm{O} / \mathrm{K}_{2} \mathrm{O}\right)-\log \left(\mathrm{SiO}_{2} / \mathrm{Al}_{2} \mathrm{O}_{3}\right)$ [Varga et al., 2007], модифицированной после [Pettijohn et al., 1972] (рис. 6) точки составов пород верхней части оселковой серии попали в поля аркозов и лититов, тогда как фигуративные точки пород нижней части оселковой серии сместились от полей субаркозов и аркозов в поле пород, демонстрирующих потерю $\mathrm{Na}_{2} \mathrm{O}$ [Varga et al., 2007].

Песчаники и гравелиты марнинской свиты характеризуются высокими содержаниями $\mathrm{SiO}_{2}$ (88.64-92.40 мас. \%). Величина гидролизатного модуля (ГМ) изменяется в них от 0.05 до 0.08, что, в соответствии с классификацией Я.Э. Юдовича и М.П. Кетрис, позволяет отнести их к гипер- и суперсилитам [Yudovich, Ketris, 2000]. Значения титанового модуля (ТМ) варьируются от 0.01 до 0.04 и указывают на гипо- и нормотитанистость этих песчаников и гравелитов. Значения железного модуля (ЖМ) изменяются от 0.15 до 0.38 , что позволяет классифицировать эти породы как гипо- и норможелезистые силиты. Величина фемического модуля (ФМ=0.01-0.02) указывает на гипофемичность исследованных пород. Значения модуля общей нормированной щелочности (НКМ=0.56-0.75) свидетельствуют о супер- и гиперщелочности этих пород [Yudovich, Ketris, 2000].

Песчаники и гравелиты нижней подсвиты удинской свиты обнаруживают высокие концентрации $\mathrm{SiO}_{2}$ (84.57-96.75 мас. \%) и разброс значений гидролизатного (ГМ), титанового (ТМ) и железного (ЖМ) литохимических модулей. Так, величина ГМ варьируется от 0.03 до 0.13, что позволяет классифицировать их как гипер-, супер- и нормосилиты. Значения ТМ изменяются от 0.01 до 0.14 и отвечают всем хемотипам силитов по величине этого 


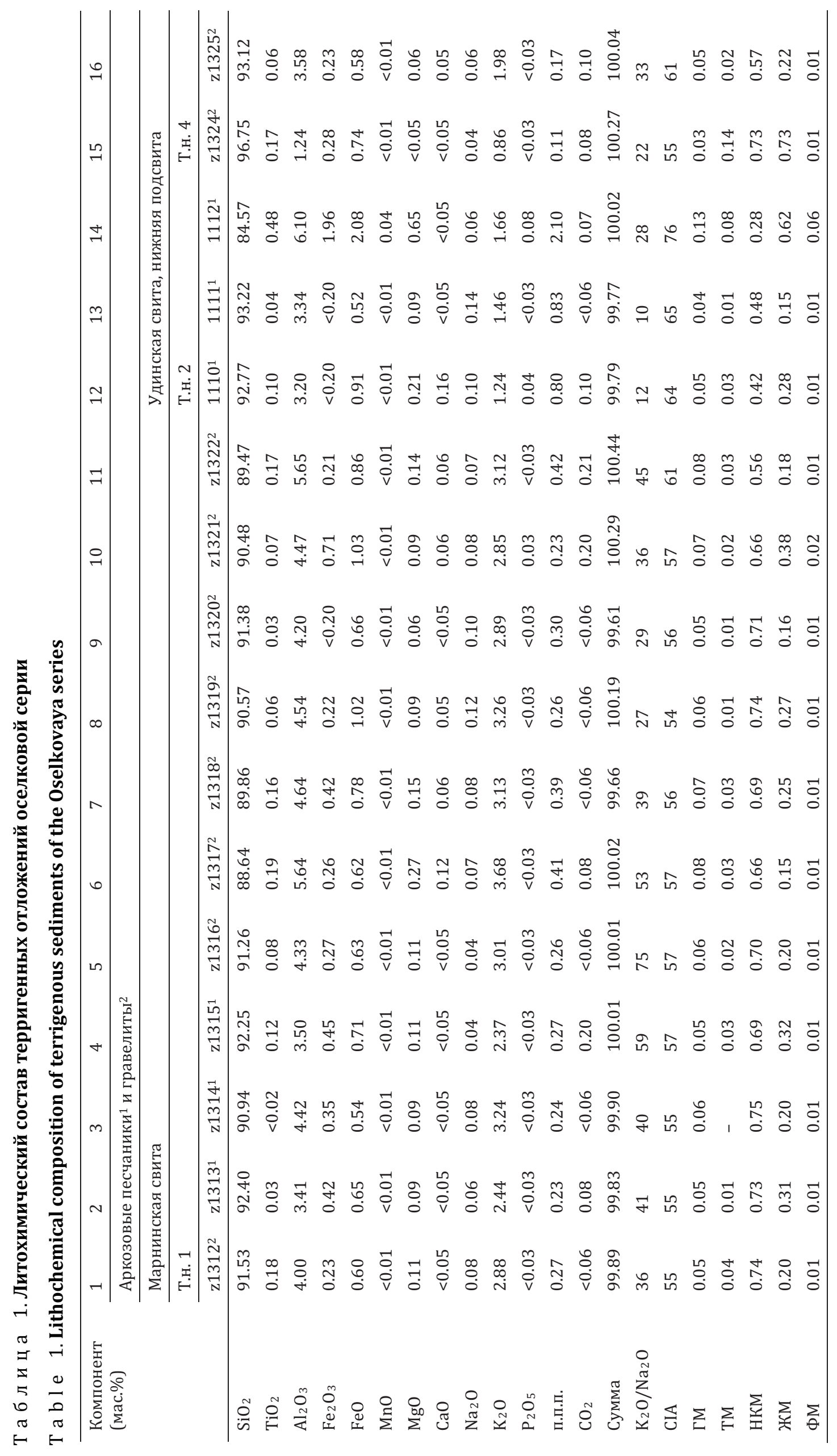




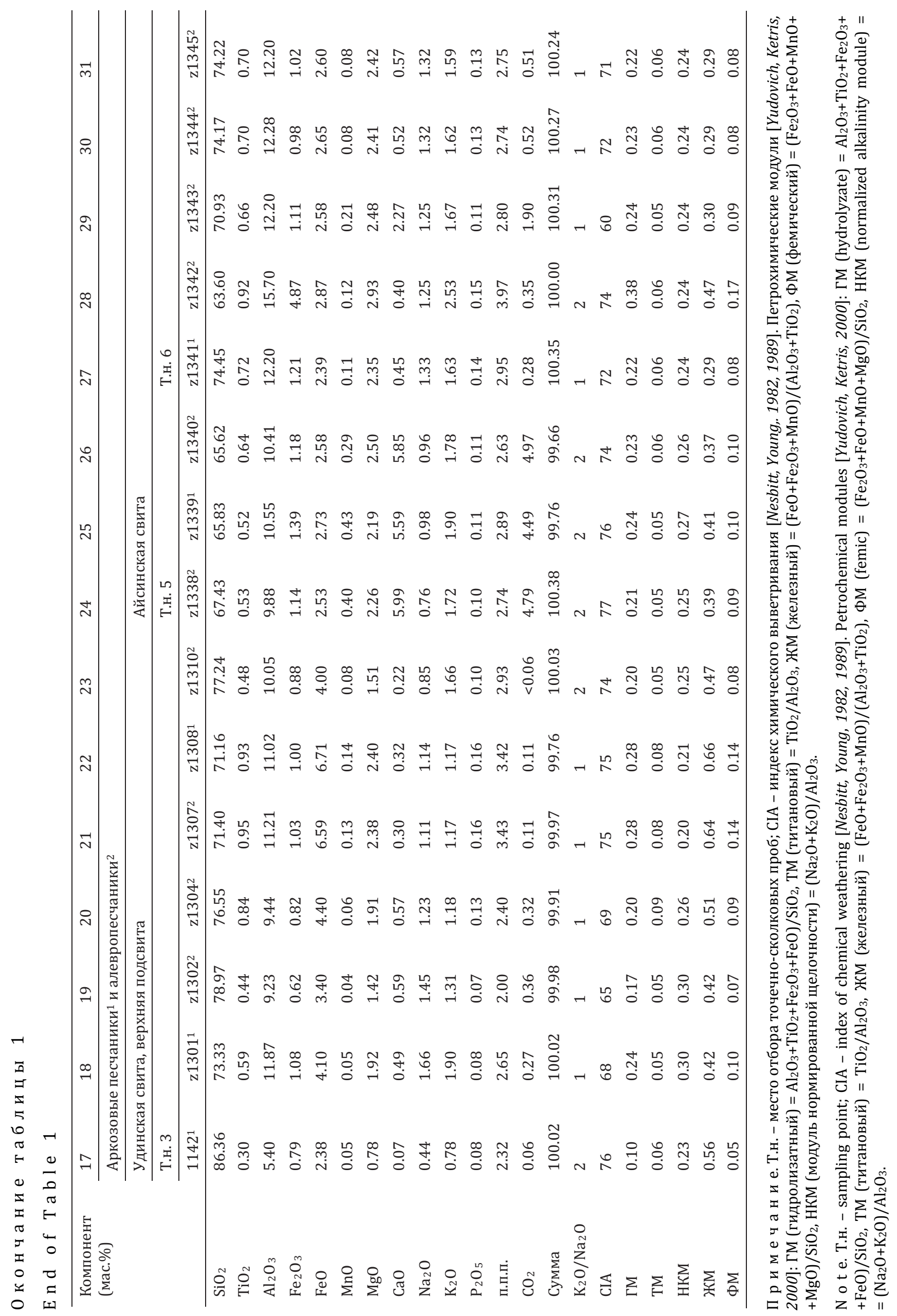




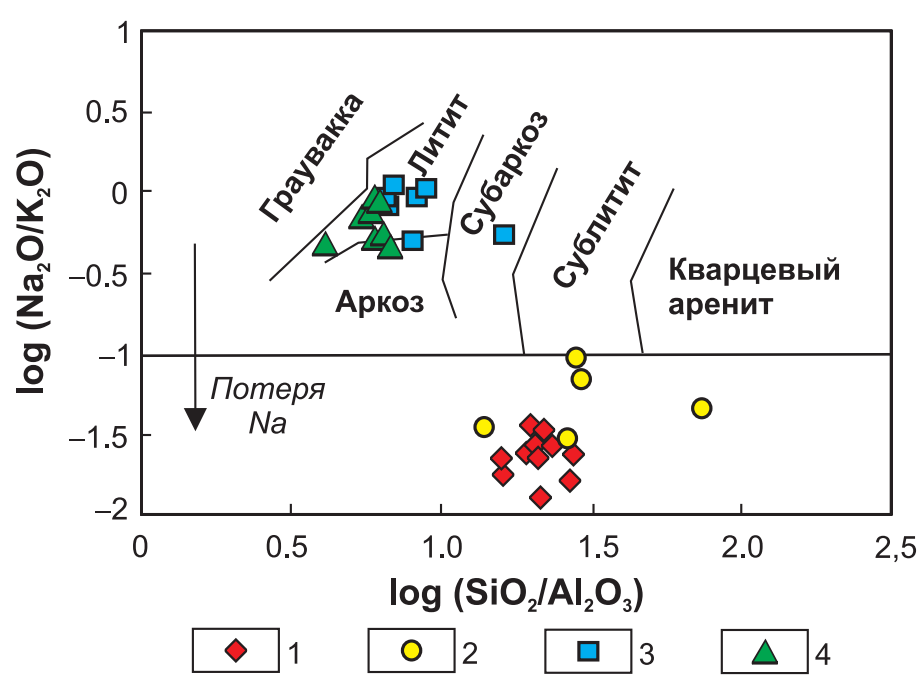

Рис. 6. Классификационная диаграмма $\log \left(\mathrm{Na}_{2} \mathrm{O} / \mathrm{K}_{2} \mathrm{O}\right)-$ $\log \left(\mathrm{SiO}_{2} / \mathrm{Al}_{2} \mathrm{O}_{3}\right)$ для песчаников [Varga et al., 2007], модифицированная после [Pettijohn et al., 1972]. Условные обозначения см. рис. 4.

Fig. 6. Classification diagram $\log \left(\mathrm{Na}_{2} \mathrm{O} / \mathrm{K}_{2} \mathrm{O}\right)-\log \left(\mathrm{SiO}_{2} /\right.$ $\mathrm{Al}_{2} \mathrm{O}_{3}$ ) for sandstones [Varga et al., 2007], modified after [Pettijohn et al., 1972]. Symbols in Fig. 4.

модуля от гипо- до гипертитанистых. Значения ЖМ варьируются от 0.15 до 0.73 и отвечают гипо-, нормо- и супержелезистым силитам. Значения фемического модуля (ФМ) изменяются от 0.01 до 0.06, что указывает на гипо- и нормофемичность этих пород. Модуль нормированной щелочности (НКМ) изменяется от 0.28 до 0.73 и позволяет отнести их к нормо-, супер- и гиперщелочным породам [Yudovich, Ketris, 2000].

Песчаники и алевропесчаники верхней подсвиты удинской свиты обнаруживают содержания $\mathrm{SiO}_{2}$ от 71.16 до 86.36 мас. \%. Значения гидролизатного модуля (ГМ) варьируются от 0.10 до 0.28, что позволяет классифицировать эти породы как нормо- и миосилиты. По значениям титанового модуля (TM=0.05-0.08) породы этой группы относятся к нормотитанистым. Значения железного модуля (ЖМ=0.47-0.66) свидетельствуют о норможелезистости этих пород. Значения фемического модуля (ФМ=0.05-0.14) указывают на нормо- и суперфемичность. Величина модуля нормированной щелочности (НКМ=0.20-0.30) позволяет классифицировать песчаники и алевропесчаники верхней подсвиты удинской свиты как нормощелочные [Yudovich, Ketris, 2000].

В составе алевропесчаников айсинской свиты содержания $\mathrm{SiO}_{2}$ варьируются от 64.60 до 74.45 мас. \%. Значения ГМ для большинства алевропесчаников варьируются в пределах от 0.21 до 0.24 , что позволяет классифицировать эти породы как миосилиты. Исключение составил один образец (z1342), значение модуля ГМ для которого равно 0.38, что дало основание отнести его к нормосиаллитам. Величина значений титанового модуля (TM=0.05-0.06) свидетельствует о нормотитанистости этих пород. Значения железного модуля (ЖМ=0.29-0.47) указывают на норможелезистость пород этой группы. Величина фемического модуля (ФМ=0.08-0.17) позволяет отнести породы этой группы к нормо- и суперфемическим. По величине значений модуля нормированной щелочности (НКМ=0.24-0.27) породы айсинской свиты относятся к нормощелочным [Yudovich, Ketris, 2000].

Характерной особенностью песчаников и гравелитов нижней части оселковой серии (марнинская и нижняя подсвита удинской свиты) являются очень низкие содержания $\mathrm{Na}_{2} \mathrm{O}$ при практически полном отсутствии $\mathrm{CaO}$ (табл. 1, рис. 7). Для песчаников и гравелитов марнинской свиты отмечаются концентрации $\mathrm{K}_{2} \mathrm{O}$ от 2.37 до 3.68 мас. \%, содержания $\mathrm{Na}_{2} \mathrm{O}$ - от 0.04 до 0.12 мас. \%, отношение $\mathrm{K}_{2} \mathrm{O} / \mathrm{Na}_{2} \mathrm{O}$ изменяется от 27 до 75. Песчаники нижней части удинской свиты обнаруживают содержания $\mathrm{K}_{2} \mathrm{O}=0.86-1.98$ мас. \% и $\mathrm{Na}_{2} \mathrm{O}=0.04-0.14$ мас. \%, отношение $\mathrm{K}_{2} \mathrm{O} / \mathrm{Na}_{2} \mathrm{O}$ варьируется от 10 до 33. Породы верхней части удинской свиты, а также айсинской свиты характеризуются концентрациями $\mathrm{K}_{2} \mathrm{O}$ от 0.78 до 2.53 мас. \% и $\mathrm{Na}_{2} \mathrm{O}$ от 0.44 до 1.66 мас. \%, величина $\mathrm{K}_{2} \mathrm{O} / \mathrm{Na}_{2} \mathrm{O}$ в этих породах составляет 1-2 (табл. 1, рис. 7).

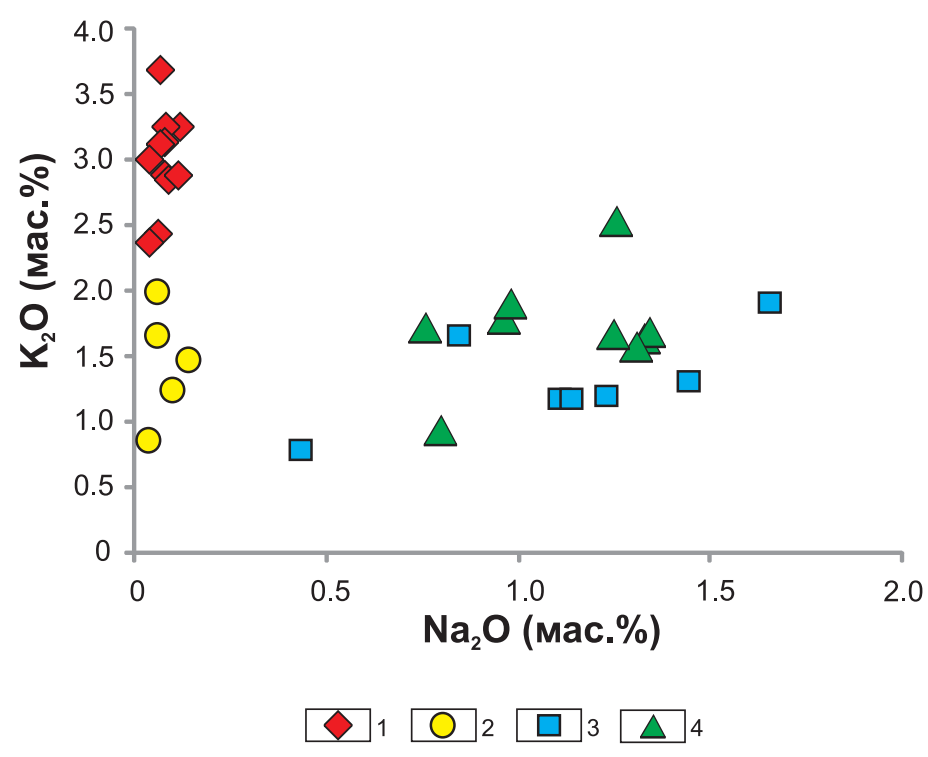

Рис. 7. Диаграмма $\mathrm{K}_{2} \mathrm{O}-\mathrm{Na}_{2} \mathrm{O}$ для терригенных пород оселковой серии. Условные обозначения см. рис. 4.

Fig. 7. Diagram $\mathrm{K}_{2} \mathrm{O}-\mathrm{Na}_{2} \mathrm{O}$ for terrigenous rocks of the Oselkovaya series. Symbols in Fig. 4. 


\section{2. РЕДКИЕ И РЕДКОЗЕМЕЛЬНЫЕ ЭЛЕМЕНТЫ}

Содержания редких и редкоземельных элементов в проанализированных породах оселковой серии приведены в таблице 2. Для наглядного представления особенностей распределения этих элементов в изученных породах приведено их сопоставление со средним протерозойским песчаником [Condie, 1993] (далее по тексту - песчаник К. Конди).

\subsection{1. Крупноионные литофильные элементы}

Терригенные породы низов оселковой серии обнаруживают повышенные концентрации Rb и Ba относительно песчаника К. Конди, для которого принимаются содержания $\mathrm{Rb}=30$ г/т, $\mathrm{Ba}=190$ г/т. В частности, отмечаются повышенные содержания этих элементов в песчаниках и гравелитах марнинской свиты $\left(\mathrm{Rb}_{\mathrm{cp} .}=74\right.$ г/T, Ba $\mathrm{a}_{\mathrm{cp}}=929$ г/т) и гравелитах и песчаниках нижней части удинской свиты $\left(\mathrm{Rb}_{\mathrm{cp} .}=41\right.$ г/т, Ba $\mathrm{a}_{\mathrm{cp}}=257$ г/т). Для пород верхней части удинской свиты и айсинской свиты фиксируются более высокие по сравнению с песчаником К. Конди концентрации $\mathrm{Rb}$ и сходные содержания $\mathrm{Ba}\left(\mathrm{Rb}\right.$ ср. $=49 \quad г / \mathrm{T}, \mathrm{Ba}_{\mathrm{cp} .}=175 \quad г / \mathrm{T}$ и $\mathrm{Rb}_{\mathrm{cp} .}=67 \quad \Gamma / \mathrm{T}$, $\mathrm{Ba}_{\mathrm{cp} .}=236$ г/T) в терригенных породах верхней части удинской свиты и айсинской свиты, соответственно (табл. 2).

Для всех исследуемых образцов отмечается выраженная положительная корреляция $\mathrm{K}_{2} \mathrm{O}$ с $\mathrm{Rb}$ $(\mathrm{r}=0.9)$ и Ва (r=0.8) (рис. 8, $a$, б), что свидетельствует о совместном нахождении этих элементов.

\subsection{2. Элементы группы железа}

Содержания Со и $\mathrm{Ni}$ в песчаниках и гравелитах марнинской свиты $\left(\mathrm{Co}_{\mathrm{cp}}=2\right.$ г/т, $\mathrm{Ni}_{\text {cp. }}=10$ г/т), а также нижней подсвиты удинской свиты $\left(\mathrm{Co}_{\mathrm{cp}}=4 \mathrm{r} / \mathrm{T}\right.$, $\mathrm{Ni}_{\text {cp. }}=15$ г/т) близки таковым в песчанике К. Конди $(\mathrm{Co}=3$ г/т, Ni=11 г/т). В то же время породы верхней части оселковой серии демонстрируют повышение концентраций Со и Ni в 3-4 раза относительно указанного эталона: верхняя подсвита удинской свиты $-\mathrm{Co}_{\text {ср. }}=12$ г/т, $\mathrm{Ni}_{\text {cp. }}=37$ г/т, айсинская свита $\mathrm{Co}_{\text {cp. }}=17$ г/т, $\mathrm{Ni}_{\text {cp. }}=45$ г/т. Следует отметить, что низкие значения Со и $\mathrm{Ni}$, характерные для песчаников и гравелитов марнинской и нижней части удинской свиты, могут свидетельствовать о преобладании кислых магматических пород в области источника сноса.

\subsection{3. Высокозарядные элементы}

Исследуемые породы оселковой серии демонстрируют разброс значений концентраций высоко- зарядных элементов (Zr, Nb, Y) (табл. 2). Песчаники и гравелиты марнинской свиты $\left(\mathrm{Zr}_{\mathrm{cp}}=72\right.$ г/т, $\mathrm{Nb}_{\text {cp. }}=2$ г/т, $\mathrm{Y}_{\text {cp. }}=5$ г/т), а также нижней подсвиты удинской свиты $\left(\mathrm{Zr}_{\mathrm{cp}}=133\right.$ г/т, $\mathrm{Nb}_{\mathrm{cp} .}=5$ г/т, $\mathrm{Y}_{\mathrm{cp} .}=8$ г/т) обнаруживают пониженные концентрации этих элементов относительно песчаников и алевропесчаников верхней подсвиты удинской свиты $\left(\mathrm{Zr}_{\mathrm{cp} .}=206 r / \mathrm{T}, \mathrm{Nb}_{\mathrm{cp} .}=10\right.$ г/T, $\mathrm{Y}_{\mathrm{cp} .}=26$ г/т), а также алевропесчаников айсинской свиты $\left(\mathrm{Zr}_{\mathrm{cp}}=183 \quad \Gamma / \mathrm{T}\right.$, $\mathrm{Nb}_{\text {cp. }}=10$ г/T, $\mathrm{Y}_{\text {cp. }}=26$ г/т). При этом концентрации этих элементов в породах нижней части оселковой серии (марнинская и нижняя часть удинской свиты) являются близкими к таковым в песчанике К. Конди $(\mathrm{Zr}=89$ г/т, $\mathrm{Nb}=3.7$ г/т, $\mathrm{Y}=10.3$ г/т), тогда как для отложений верхов серии (верхняя часть удинской и айсинская свита) фиксируется превышение концентраций этих элементов более чем в два раза относительно песчаника К. Конди.

\subsection{4. Радиоактивные элементы}

Содержания радиоактивных элементов в песчаниках и гравелитах марнинской свиты $\left(\mathrm{Th}_{\mathrm{cp}}=2.3\right.$ $\Gamma / \mathrm{T}, \mathrm{U}_{\mathrm{cp}}=0.7$ г/т), а также нижней подствиты удинской свиты $\left(\mathrm{Th}_{\mathrm{cp}}=4\right.$ г/T, $\mathrm{U}_{\mathrm{cp} .}=0.9$ г/T) являются близкими таковым в песчанике К. Конди $(\mathrm{Th}=4.2$ г/т, $\mathrm{U}=1.2$ г/T). Породы верхней подсвиты удинской свиты $\left(\mathrm{Th}_{\mathrm{cp}}=15\right.$ г/т, $\mathrm{U}_{\mathrm{cp}}=2.3$ г/т) и айсинской свиты $\left(\mathrm{Th}_{\mathrm{cp}}=9\right.$ г/T, $\mathrm{U}_{\mathrm{cp} .}=2$ г/T) обнаруживают повышенные концентрации этих элементов относительно песчаника К. Конди [Condie, 1993].

\subsection{5. Редкоземельные элементы}

Породы всех трех свит оселковой серии характеризуются фракционированными спектрами распределения редкоземельных элементов $\left(\mathrm{La}_{\mathrm{n}} / \mathrm{Yb}_{\mathrm{n}}=4.7-19.8\right)$ и обогащением легкими лантаноидами относительно тяжелых (рис. 9). Для большинства пород марнинской свиты характерно отсутствие либо положительная европиевая аномалия $\left(\mathrm{Eu} / \mathrm{Eu}^{*}=0.9-2.8\right)$, только один образец (z1322) обнаруживает отрицательную европиевую аномалию $\left(\mathrm{Eu} / \mathrm{Eu}^{*}=0.6\right)$ (рис. 9, a). Породы удинской и айсинской свит демонстрируют наличие хорошо выраженной отрицательной европиевой аномалии (Eu/Eu*=0.4-0.7) (рис. 9, б, в). Для пород марнинской свиты и нижней подсвиты удинской свиты отмечаются близкие или пониженные концентрации редкоземельных элементов относительно песчаника К. Конди, в то время как для пород верхней подсвиты удинской свиты, а также айсинской свиты характерны повышенные концентрации редкоземельных элементов относительно указанного эталона (рис. 9). 


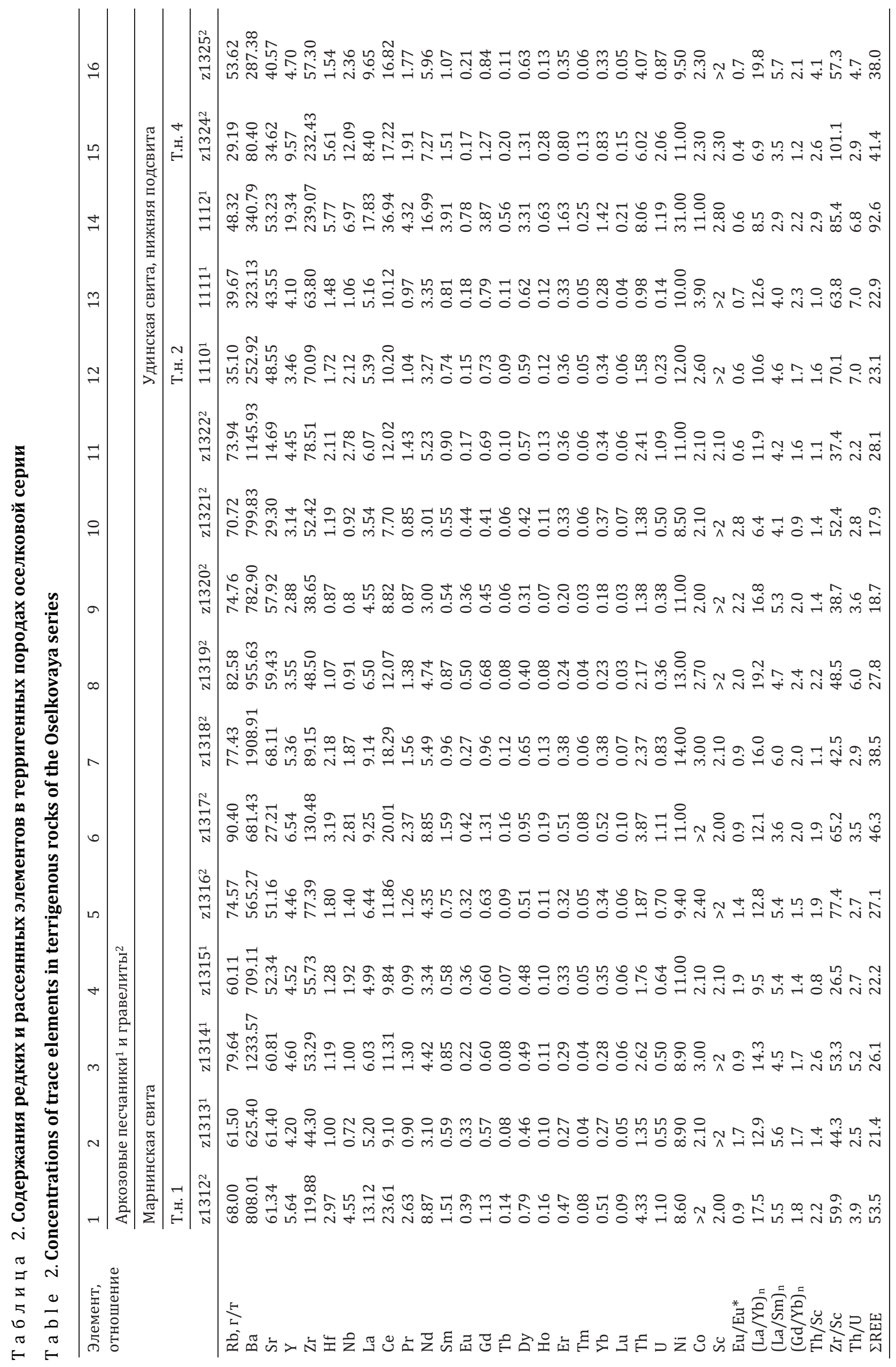




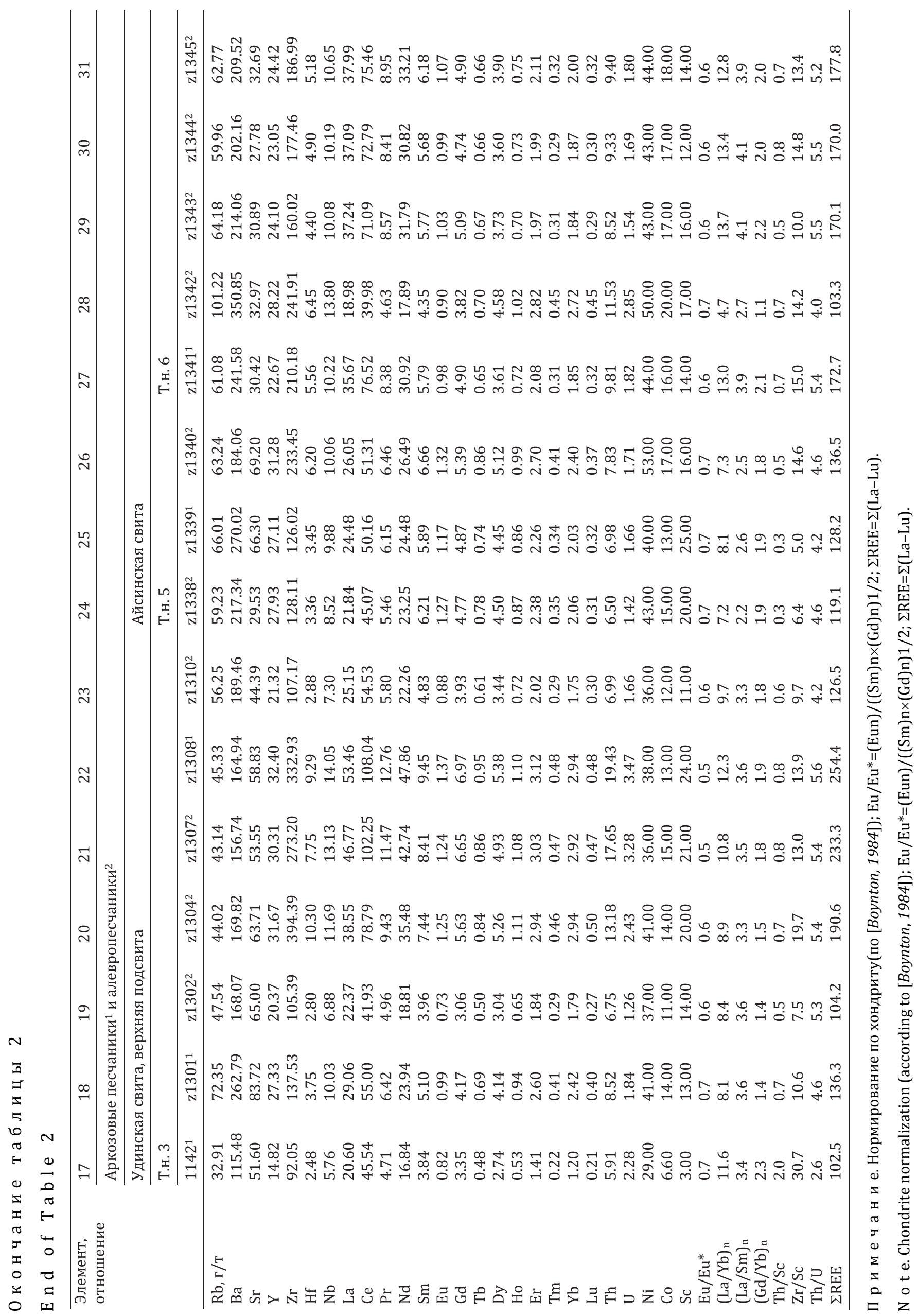



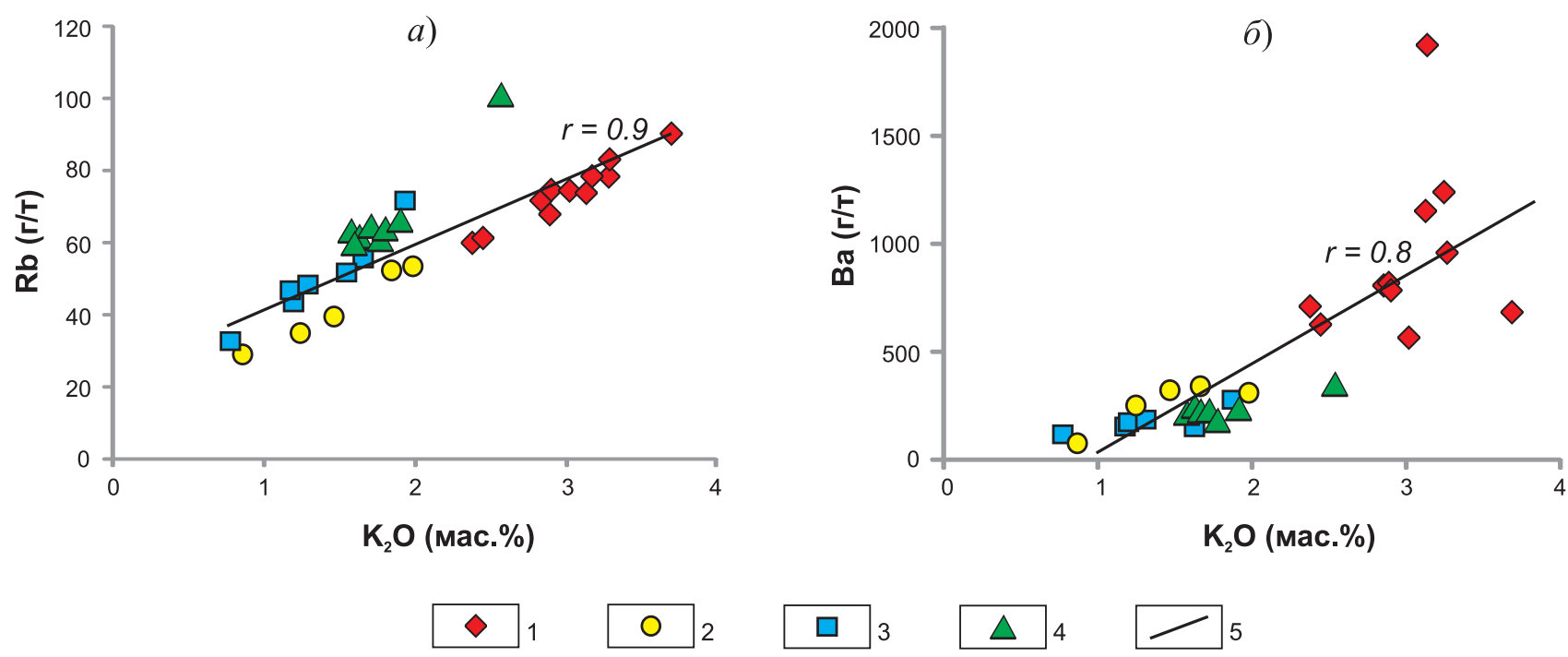

Рис. 8. Диаграммы $\mathrm{Rb}-\mathrm{K}_{2} \mathrm{O}(a), \mathrm{Ba}-\mathrm{K}_{2} \mathrm{O}$ (б) для терригенных пород оселковой серии.

1 - марнинская свита; 2 - нижняя подсвита удинской свиты; 3 - верхняя подсвита удинской свиты; 4 - айсинская свита; 5 - линия тренда.

Fig. 8. Diagrams $\mathrm{Rb}-\mathrm{K}_{2} \mathrm{O}(a)$ and $\mathrm{Ba}-\mathrm{K}_{2} \mathrm{O}$ (б) for terrigenous rocks of the Oselkovaya series.

1 - Marninskaya suite; 2 - lower part of Udinskaya suite; 3 - upper part of Udinskaya suite; 4 - Aisinskaya suite; 5 - trend line.

\section{5. ОБСУЖДЕНИЕ РЕЗУЛЬТАТОВ}

Приведенные в работе результаты исследований терригенных отложений оселковой серии свидетельствуют о том, что песчаники и гравелиты марнинской свиты и нижней части удинской свиты обнаруживают петрографические и литогеохимические характеристики, существенно отличающиеся от песчаников и алевропесчаников верхней части удинской свиты и алевропесчаников айсинской свиты. Для пород марнинской свиты характерны значительные вторичные изменения пород, в том числе регенерация калиевых полевых шпатов, выраженная гребневидным обрастанием обломочных зерен калиевых полевых шпатов аутигенным калиевым полевым шпатом, а также интенсивная пелитизация полевых шпатов с образованием глинисто-гидрослюдистого агрегата (см. рис. 5, $a$, б). Породы нижней подсвиты удинской свиты также характеризуются интенсивной пелитизацией калиевых полевых шпатов с образованием глинистогидрослюдистого агрегата, а также серицитизацией плагиоклазов (см. рис. 5, в, г). Кроме того, все образцы пород марнинской и нижней части удинской свиты обнаруживают чрезвычайно низкие концентрации $\mathrm{Na}_{2} \mathrm{O}$. Отношение $\mathrm{K}_{2} \mathrm{O} / \mathrm{Na}_{2} \mathrm{O}$ для образцов марнинской свиты варьируется от 27 до 75, а для пород нижней подсвиты удинской свиты - от 10 до 33.

Породы верхней части удинской свиты, а также айсинской свиты обнаруживают менее интенсивно проявленные вторичные изменения, которые выражены слабой пелитизацией полевых шпатов, образованием гидроокислов железа и хлоритизацией биотита. Значение $\mathrm{K}_{2} \mathrm{O} / \mathrm{Na}_{2} \mathrm{O}$ для этих пород не превышает 1-2 (см. табл. 1, рис. 5, $\partial$, е, ж, з). Петрографические и геохимические особенности, отмеченные в породах марнинской и нижней части удинской свиты, являются типичными для процессов эпигенетической проработки пород [Kopeliovich, 1965; Nozhkin, Gavrilenko, 1976; Yudovich, Ketris, 2008]. Низкие содержания $\mathrm{Na}_{2} \mathrm{O}$ в песчаниках и гравелитах марнинской и нижней части удинской свиты могут указывать на потерю $\mathrm{Na}_{2} \mathrm{O}$ в результате его высокой мобильности в процессах химического выветривания, диагенеза и катагенеза [McLennan, 2001; Varga, Szakmány, 2004; Varga et al., 2007]. В то же время в области источника сноса для терригенных отложений марнинской и нижней части удинской свиты нельзя полностью исключать и присутствие пород, имеющих низкие содержания $\mathrm{Na}_{2} \mathrm{O}$. Что касается пород верхней части удинской свиты и айсинской свиты, то они на исследуемой территории остались практически неизмененными.

\section{1. ХАРАКТЕРИСТИКА ПРОЦЕССОВ ПАЛЕОВЫВЕТРИВАНИЯ}

Степень химического изменения терригенных пород обычно определяется с помощью индекса химического выветривания CIA [Nesbitt, Young, 1982], который рассчитывается по формуле (мо- 
a)

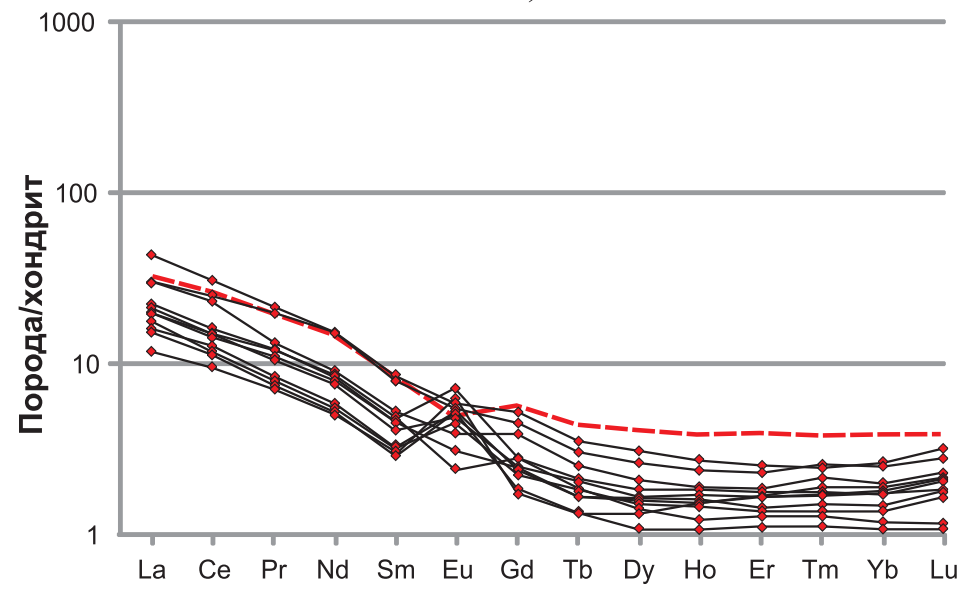

б)

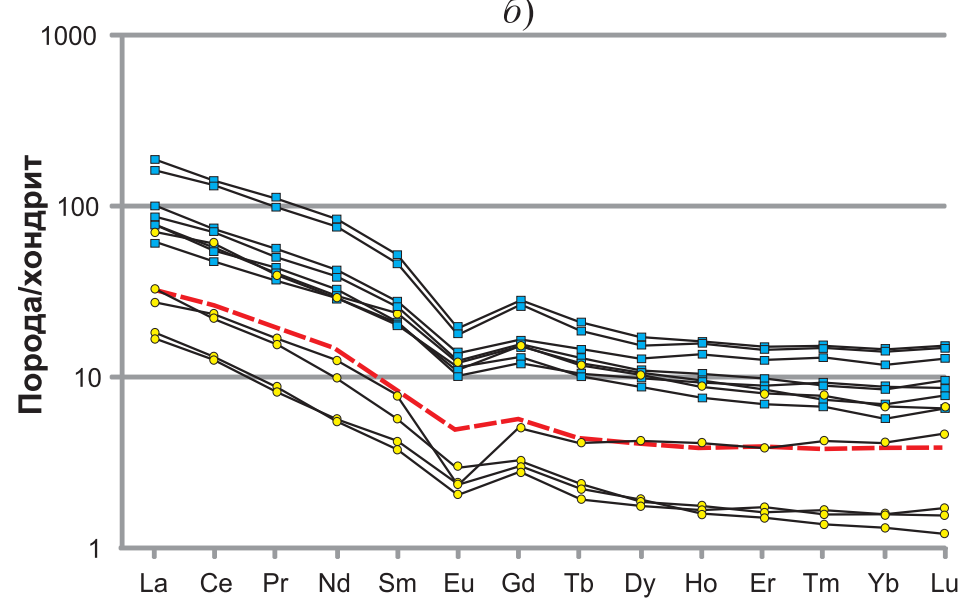

в)

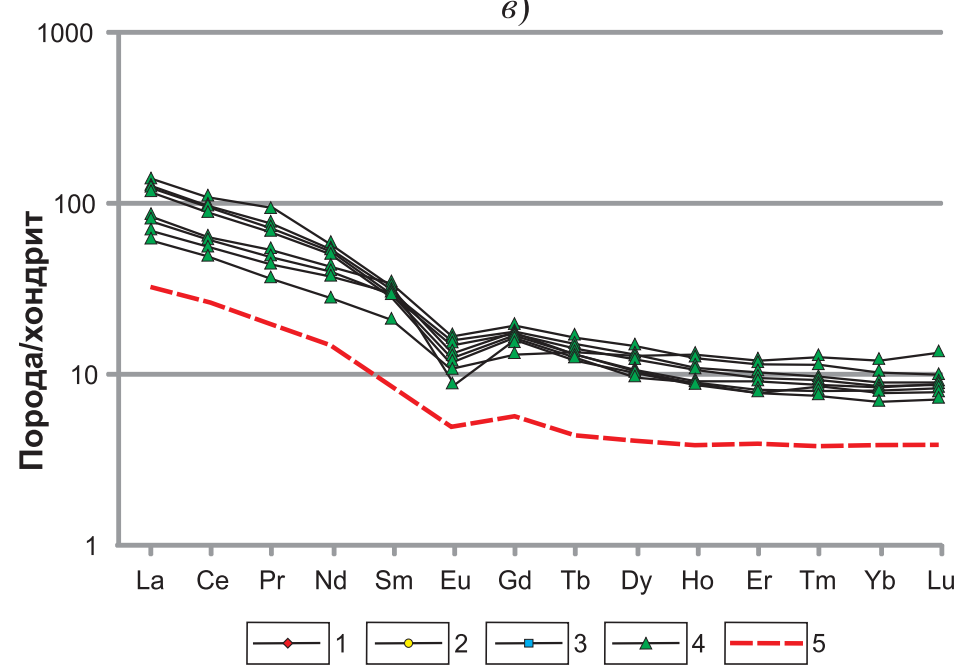

Рис. 9. Спектры распределения РЗЭ, нормированные по хондриту [Boynton, 1984] для терригенных пород марнинской $(a)$, удинской (б) и айсинской свит $(\theta)$ оселковой серии.

1 - марнинская свита; 2 - нижняя подсвита удинской свиты; 3 - верхняя подсвита удинской свиты; 4 - айсинская свита; 5 спектр распределения РЗЭ среднего протерозойского песчаника К. Конди [Condie, 1993].

Fig. 9. REE distribution spectra, chondrite normalized [Boynton, 1984] for terrigenous rocks of the Marninskaya (a), Udinskaya (б), and Aisinskaya suites ( 8 ) of the Oselkovaya series.

1 - Marninskaya suite; 2 - lower part of Udinskaya suite; 3 - upper part of Udinskaya suite; 4 - Aisinskaya suite; 5 - REE distribution spectrum of Proterozoic sandstone, according to [Condie, 1993]. 


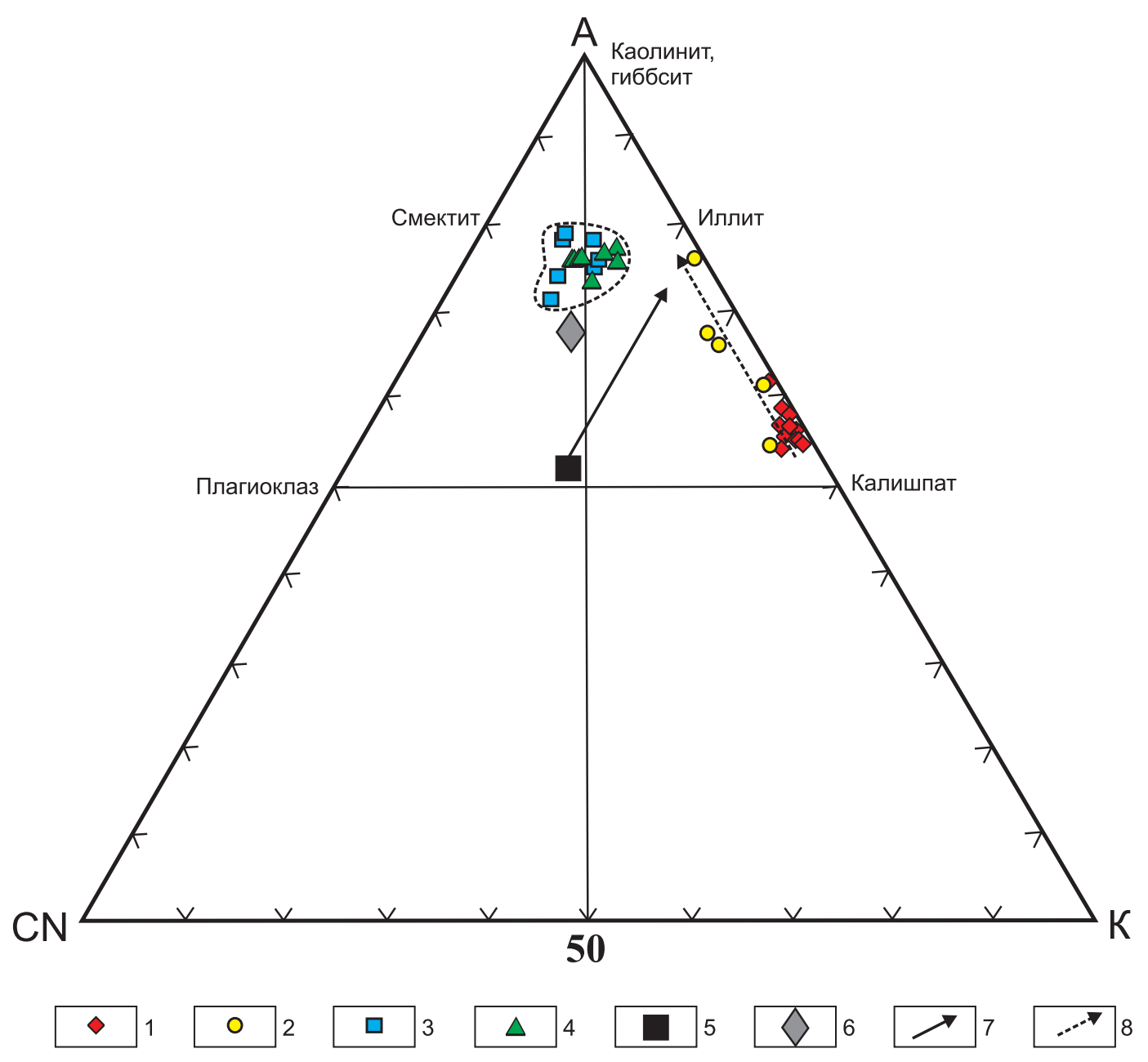

Рис. 10. Диаграмма A-CN-K $\left(\mathrm{Al}_{2} \mathrm{O}_{3}-\left(\mathrm{CaO}^{*}+\mathrm{Na}_{2} \mathrm{O}\right)-\mathrm{K}_{2} \mathrm{O}\right)$ [Nesbitt, Young, 1989] для терригенных пород оселковой серии.

1 - марнинская свита; 2 - нижняя подсвита удинской свиты; 3 - верхняя подсвита удинской свиты; 4 - айсинская свита; 5 - фигуративная точка среднего гранита [Taylor, McLennan, 1985]; 6 - фигуративная точка среднего протерозойского песчаника К. Конди [Condie, 1993]; 7 - тренд выветривания среднего гранита [Condie, 1993]; 8 - тренд выветривания исследуемых пород.

Fig. 10. Diagram A-CN-K $\left(\mathrm{Al}_{2} \mathrm{O}_{3}-\left(\mathrm{CaO}^{*}+\mathrm{Na}_{2} \mathrm{O}\right)-\mathrm{K}_{2} \mathrm{O}\right)$ [Nesbitt, Young, 1989] for terrigenous rocks of the Oselkovaya series.

1 - Marninskaya suite; 2 - lower part of Udinskaya suite; 3 - upper part of Udinskaya suite; 4 - Aisinskaya suite; 5 - figurative point of middle granite [Taylor, McLennan, 1985]; 6 - figurative point of Proterozoic sandstone, according to [Condie, 1993]; 7 - weathering trend of middle granite [Condie, 1993]; 8 - weathering trend of the studied rocks.

лекулярные массы): $\mathrm{CIA}=\left[\mathrm{Al}_{2} \mathrm{O}_{3} /\left(\mathrm{Al}_{2} \mathrm{O}_{3}+\mathrm{CaO} *+\mathrm{Na}_{2} \mathrm{O}+\right.\right.$ $\left.\left.+\mathrm{K}_{2} \mathrm{O}\right)\right]$, где $\mathrm{CaO}^{*}$ рассчитывается как доля $\mathrm{CaO}$ без учета кальция, входящего в состав карбоната. Для графического выражения степени химического изменения терригенных пород используется диаграмма A-CN-K $\left(\mathrm{Al}_{2} \mathrm{O}_{3}-\left(\mathrm{CaO}^{*}+\mathrm{Na}_{2} \mathrm{O}\right)-\mathrm{K}_{2} \mathrm{O}\right)$ [Nesbitt, Young, 1989; Sklyarov, 2001], с помощью которой можно определить направленность выветривания пород питающей провинции в процессе седиментогенеза, а также допустимость применения индекса CIA для определения степени химического выветривания [McLennan et al., 1993]. На диаграмме $\mathrm{A}-\mathrm{CN}-\mathrm{K}$ (рис. 10) точки составов пород марнинской свиты, имеющие значения $\mathrm{K}_{2} \mathrm{O} / \mathrm{Na}_{2} \mathrm{O}$ от 27 до 75, а также фигуративные точки пород нижней подсви- ты удинской свиты, значения $\mathrm{K}_{2} \mathrm{O} / \mathrm{Na}_{2} \mathrm{O}$ для которых варьируются от 10 до 33, образуют тренд, параллельный линии А-К. Такой тренд может свидетельствовать о том, что эти породы были подвержены эпигенетическим преобразованиям [Yapaskurt, 1994; Yudovich, Ketris, 2008], в процессе которых произошел вынос $\mathrm{Na}_{2} \mathrm{O}$ [McLennan, 2001; Varga, Szakmány, 2004; Varga et al., 2007], а также распад калиевых полевых шпатов, приводящий к их глинизации и регенерации [Fedo et al., 1995]. Подобные изменения терригенных пород марнинской и нижней части удинской свиты не позволяют в полной мере использовать индекс CIA [Nesbitt, Young, 1982], так как при его расчете учитываются содержания $\mathrm{Na}_{2} \mathrm{O}$. 


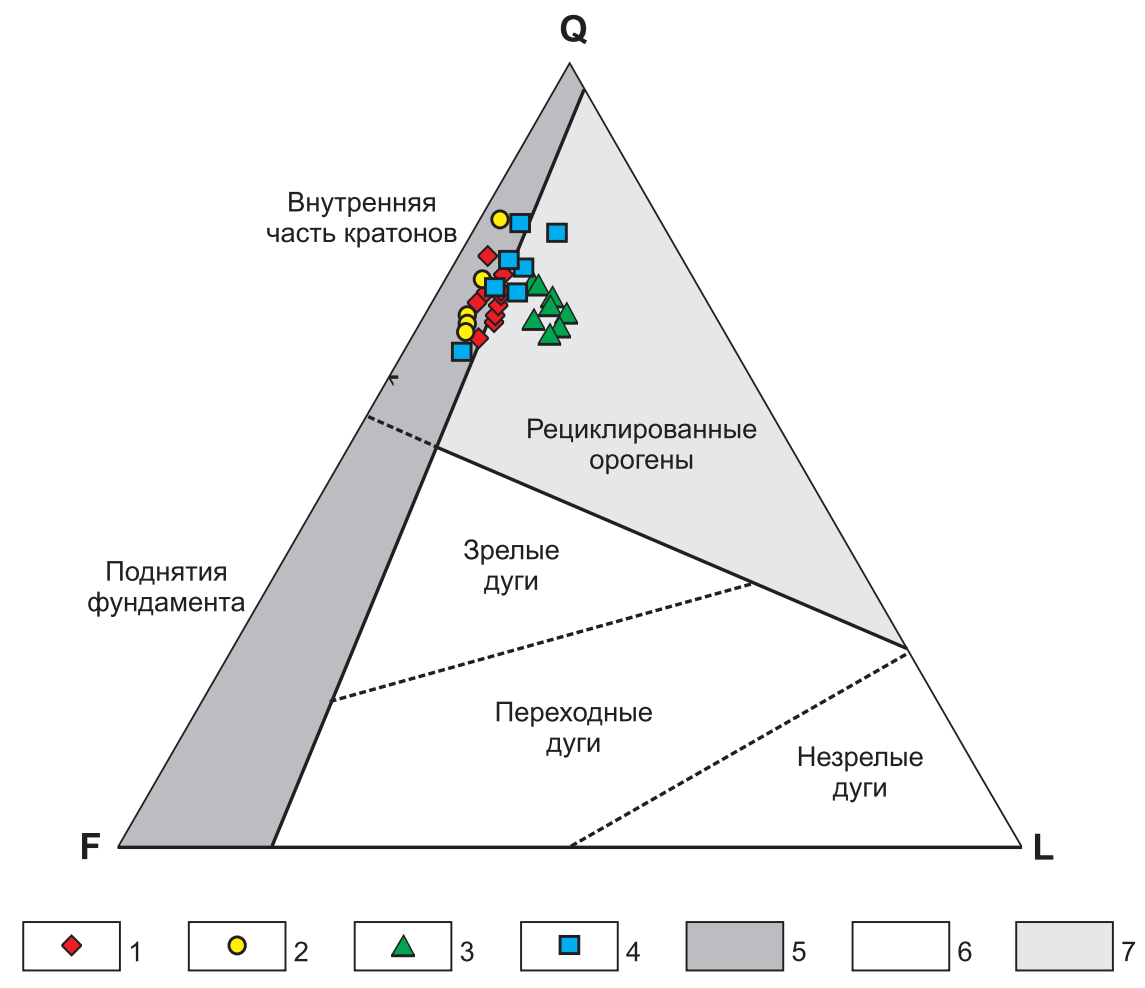

Рис. 11. Диаграмма F-Q-L (полевые шпаты - кварц - обломки пород) [Dickinson et al., 1983] для терригенных пород оселковой серии.

1 - марнинская свита; 2 - нижняя подсвита удинской свиты; 3 - верхняя подсвита удинской свиты;4 - айсинская свита; 5-7 группы источников: 5 - континентальный блок, 6 - магматические дуги, 7 - рециклированные орогены.

Fig. 11. Diagram F-Q-L (feldspar - quartz - rock fragments) [Dickinson et al., 1983] for terrigenous rocks of the Oselkovaya series.

1 - Marninskaya suite; 2 - lower part of Udinskaya suite; 3 - upper part of Udinskaya suite; 4 - Aisinskaya suite; 5-7 - group of sources: 5 - continental block, 6 - magmatic arc, 7 - recycled orogenes.

Точки составов песчаников и алевропесчаников верхней подсвиты удинской свиты, а также айсинской свиты, значения $\mathrm{K}_{2} \mathrm{O} / \mathrm{Na}_{2} \mathrm{O}$ для которых не превышают 1-2, на диаграмме A-CN-K образуют поле, расположенное вблизи фигуративной точки среднего протерозойского песчаника К. Конди [Condie, 1993], а также вдоль тренда прогрессивного выветривания гранитов [Sklyarov, 2001]. Такое расположение фигуративных точек допускает возможность применения индекса СIA для этих пород [McLennan, 2001]. Значения индекса CIA для пород верхней части разреза оселковой свиты составляют 69-80, что указывает на достаточно сильную степень химического преобразования пород в области источника сноса [Nesbitt, Yong, 1982].

\section{2. Источники сносА}

Терригенные породы нижней части оселковой серии (марнинская свита и нижняя часть удинской свиты) в основном сложены плохо отсортированным полуокатанным и неокатанным материа- лом (см. рис. 5, $a, 6,8,2$ ), что может указывать на близость пород источника к бассейну седиментации. Расположение фигуративных точек пород марнинской и нижней части удинской свиты оселковой серии на диаграмме F-Q-L (полевые шпатыкварц-обломки пород) (рис. 11) [Dickinson et al., 1983] свидетельствует о том, что они образовались в основном за счет разрушения пород внутренней части кратона. Породы верхней части удинской свиты и айсинской свиты отличаются от пород нижней части серии более тонкозернистым составом алевропесчаниковой размерности, различной степенью окатанности обломочного материала, а также средней сортировкой (см. рис. 5, $\partial$, , ж, 3), что указывает на отдаленность области источника от бассейна седиментации этих пород. На рис. 11 точки их составов расположились преимущественно в поле пород, образованных за счет размыва рециклированных орогенов.

Обломки пород в образцах марнинской и нижней части удинской свиты оселковой серии представлены гранитоидами, кварцитами и кислыми 
a)

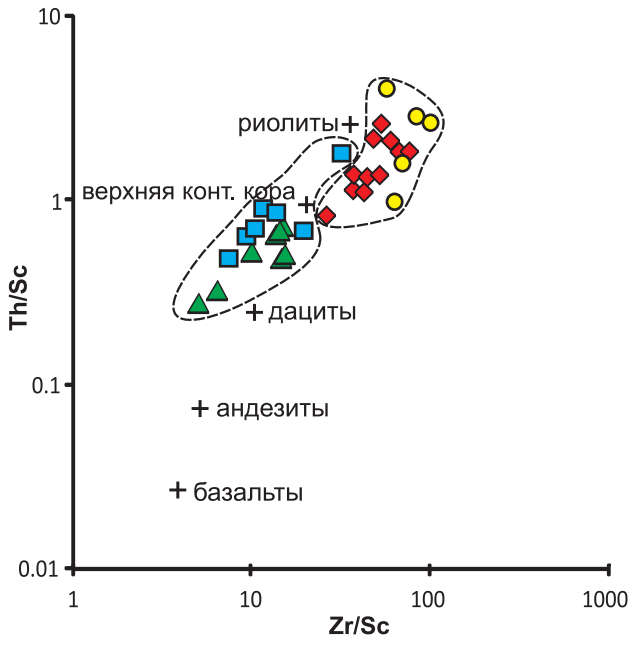

б)

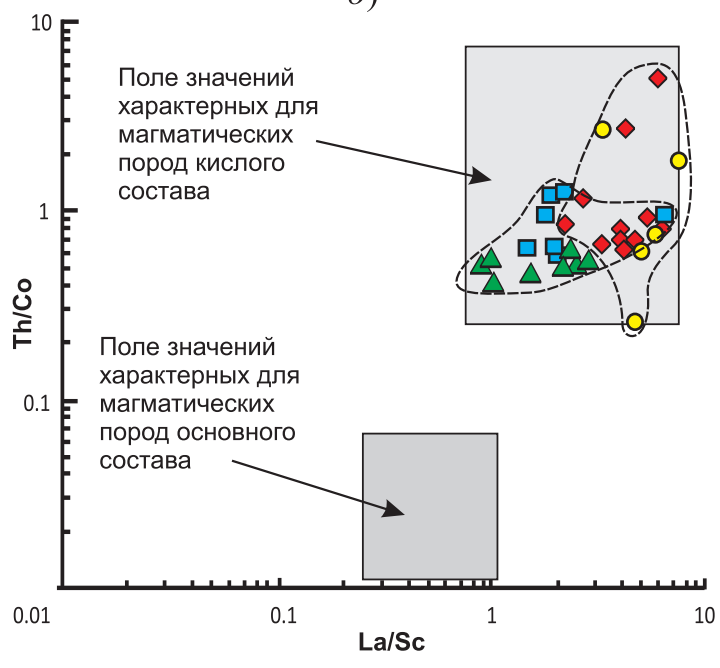

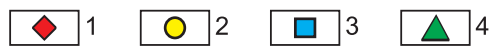

Рис. 12. Диаграммы Th/Sc-Zr/Sc (a) [McLennan et al., 1993] и Th/Co-La/Sc (б) [Cullers, 2002] для терригенных пород оселковой серии.

1 - марнинская свита; 2 - нижняя подсвита удинской свиты; 3 - верхняя подсвита удинской свиты; 4 - айсинская свита.

Fig. 12. Diagrams Th Th/Sc-Zr/Sc (a) [McLennan et al., 1993] and Th/Co-La/Sc (б) [Cullers, 2002] for terrigenous rocks of the Oselkovaya series.

1 - Marninskaya suite; 2 - lower part of Udinskaya suite; 3 -upper part of Udinskaya suite; 4 - Aisinskaya suite.

эффузивами. В породах верхней части удинской свиты и айсинской свиты, наряду с гранитоидами и кварцитами, также отмечаются обломки аргиллитов, алевролитов и эффузивов кислого и основного состава (см. рис. 5, $\partial, е$, ж, 3). Акцессорные минералы, отмеченные в породах марнинской и удинской свит, в основном характерны для пород кислого состава (апатит, турмалин, циркон, сфен). В минеральном составе образцов пород айсинской свиты, вместе с указанными выше акцессориями, отмечаются зерна эпидота, типичные для пород основного состава.

Все исследуемые породы оселковой серии характеризуются фракционированными спектрами распределения редкоземельных элементов и обогащением легкими лантаноидами относительно тяжелых $\left(\mathrm{La}_{\mathrm{n}} / \mathrm{Yb}_{\mathrm{n}}=4.7-19.8\right)$. Для пород удинской и айсинской свит, а также одного образца марнинской свиты (обр. z1322) отмечается наличие отрицательной европиевой аномалии $\left(\mathrm{Eu} / \mathrm{Eu}^{*}=0.5-0.7\right)$ (см. табл. 2, рис. 9), что свидетельствует о преобладании в области источника магматических пород кислого состава. Для большинства песчаников и гравелитов марнинской свиты отмечается отсутствие или положительная европиевая аномалия $\left(\mathrm{Eu} / \mathrm{Eu}^{*}=0.9-2.8\right)$ на спектрах РЗЭ (см. рис. 9, $\left.a\right)$, однако эти образцы не обнаруживают каких-либо отличий в петрографическом составе от остальных исследуемых пород нижней части оселковой серии, и, следовательно, такое распределение редкоземельных элементов может быть связано с различной степенью эпигенетических изменений и не отражает при этом первичный состав источника.

Как было отмечено выше, терригенные породы марнинской свиты и нижней части удинской свиты обнаруживают геохимические характеристики, отличные от пород верхней части удинской свиты и айсинской свиты, что может свидетельствовать о разных источниках сноса для пород нижней и верхней части разреза оселковой серии. Этот вывод подтверждается расположением фигуративных точек пород низов и верхов оселковой серии на диаграммах Th/Sc-Zr/Sc (рис. 12, a) [McLennan et al., 1993] и Th/Co-La/Sc (рис. 12, б) [Cullers, 2002], где они образуют два отдельных кластера, при этом наблюдается смещение фигуративных точек пород верхов оселковой серии к точкам состава основных пород. Таким образом, для терригенных пород марнинской свиты и нижней части удинской свиты в качестве основного источника сноса принимаются породы кислого состава. Что касается пород верхней части удинской и айсинской свиты, то их источник сноса мог иметь смешанный состав (породы кислого и основного состава), что также подтверждается набором обломков пород и акцессорных минералов.

Принимая во внимание результаты исследований [Sovetov, Komlev, 2005; Sovetov, 2011; Sovetov et 
al., 2015; Sklyarov, 2006; Letnikova et al., 2013; Motova, 2016], а также учитывая описанные в настоящей работе особенности петрографического и литогеохимического состава песчаников и гравелитов марнинской и нижней части удинской свиты, можно предположить, что они образовались за счет разрушения архей-раннепротерозойских пород фундамента Сибирского кратона. Этот вывод подтверждается и имеющимися данными по U-Pb исследованиям детритовых цирконов нижней части оселковой серии, в результате которых были получены возрастные спектры архейского и раннепротерозойского возраста [Sovetov et al., 2015; Motova, 2016], что соответствует возрасту пород фундамента Сибирского кратона [Rojas-Agramonte et al., 2011]. Большое количество цирконов с возрастом 1.90-1.85 млрд лет в проанализированных терригенных породах свидетельствует о том, что граниты саянского комплекса и вулканиты елашской серии, широко распространенные в Бирюсинском блоке [Levitskii et al., 2002; Turkina et al., 2003, 2006; Donskaya et al., 2014, 2016], могли быть одним из основных источников материала, поступающего в бассейн седиментации. Кроме того, кислые вулканиты мальцевской толщи елашской серии с возрастом 1.87 млрд лет, для которых характерны пониженные содержания $\mathrm{Na}_{2} \mathrm{O}(0.1-2.5$ г/т) [Donskaya et al., 2016], могут рассматриваться как источники пород с низкими содержаниями Na.

Для пород верхней части удинской и айсинской свиты предполагается другой источник сноса, отличный от пород нижней части оселковой серии. Возможно, что породы верхней части удинской и айсинской свиты образовались как за счет разрушения пород орогена, сформированного в венде в результате аккреции микроконтинентов и островных дуг Палеоазиатского океана к юго-западной окраине Сибирского кратона [Nozhkin et al., 2007], так и за счет разрушения пород фундамента Сибирского кратона. Это предположение подтверждают данные о возрасте детритовых цирконов из отложений верхней части оселковой серии, а именно верхней части удинской и айсинской свиты [Letnikova et al., 2013; Sovetov et al., 2015; Motova, 2016], возрастные спектры по которым, наряду c архей-раннепротерозойскими, обнаруживают обильную популяцию детритовых цирконов неопротерозойского возраста, не характерных для пород фундамента Сибирского кратона.

\section{6. ЗАКЛЮЧЕНИЕ}

Основываясь на полученных в ходе проведенных исследований результатах, можно сделать следующие выводы:
1. Породы нижней и верхней части разреза позднедокембрийской оселковой серии обнаруживают различные петрографические характеристики. Так, низы разреза серии (марнинская и нижняя часть удинской свиты) характеризуются более грубозернистым составом обломочных пород (гравелиты и песчаники) относительно верхов серии (верхняя часть удинской и айсинская свита песчаники и алевропесчаники). При этом отмечается увеличение степени окатанности и сортировки обломочного материала вверх по разрезу. Кроме того, в гравелитах и песчаниках нижней части оселковой серии диагностируются признаки эпигенетических преобразований, проявленные интенсивной пелитизацией и регенерацией кварца и калиевых полевых шпатов. Песчаники и алевропесчаники верхней части оселковой серии обнаруживают менее интенсивно выраженные эпигенетические изменения, проявленные слабой пелитизацией полевых шпатов и хлоритизацией биотита.

2. Наряду с петрографическими различиями, для пород верхней и нижней части оселковой серии отмечаются существенные литохимические отличия. Так, породы низов серии обнаруживают весьма низкие содержания $\mathrm{Na}_{2} \mathrm{O}$, значение $\mathrm{K}_{2} \mathrm{O} / \mathrm{Na}_{2} \mathrm{O}$ в них изменяется от 10 до 75. Для терригенных отложений верхней части серии величины $\mathrm{K}_{2} \mathrm{O} / \mathrm{Na}_{2} \mathrm{O}$ не превышают 1-2. Кроме того, песчаники и гравелиты нижней части оселковой серии характеризуются пониженными концентрациями радиоактивных (Th, U), редкоземельных, высокозарядных (Zr, Nb, Y) элементов, а также $\mathrm{Ni}$ и Со относительно концентраций этих элементов в песчаниках и алевропесчаниках верхней части оселковой серии.

3. Отмеченные различия в петрографических и литогеохимических характеристиках терригенных отложений нижней и верхней части оселковой серии могут свидетельствовать о разных источниках обломочного материала, поступавшего в бассейн седиментации в начале и конце периода накопления отложений оселковой серии. Для терригенных пород нижней части серии в качестве основного источника сноса могут быть приняты породы кислого состава, а для песчаников и алевропесчаников верхней части серии предполагается, что источник сноса мог иметь смешанный (кислый - основной) состав.

4. Проведенная реконструкция состава пород в области источников сноса с учетом имеющихся данных о возрасте детритовых цирконов из песчаников верхней и нижней части оселковой серии позволяет предположить, что низы оселковой серии образовались за счет разрушения пород 
фундамента Сибирского кратона. Верхняя часть оселковой серии могла быть образована в бассейне, снос кластики в который осуществлялся с орогена, сформировавшегося в результате аккреции микроконтинентов и островных дуг Палеоазиатского океана к юго-западной окраине Сибирского кратона.

\section{7. БЛАГОДАРНОСТИ}

Авторы выражают благодарность Т.А. Корниловой за консультации и ценные замечания при петрографическом исследовании терригенных пород. Работа выполнена при поддержке РНФ (проект №16-17-10180).

\section{8. ЛИТЕРАTУРА / REFERENCES}

Boynton W.V., 1984. Cosmochemistry of the rare earth elements; meteorite studies. In: P. Henderson (Ed.), Rare earth element geochemistry. Developments in Geochemistry. Vol. 2. Elsevier, Amsterdam, p. 63-114. http://dx.doi.org/ 10.1016/B978-0-444-42148-7.50008-3.

Bragin S.S., 1985. The use of paleomagnetic data for solution of some problems of the Late Riphean geology of Prisayanie. In: V.V. Khomentovsky (Ed.), Stratigraphy of Late Precambrian and Early Paleozoic Siberia: Vendian and Riphean. IGG SB, USSR Acad. Sci., Novosibirsk, p. 57-64 (in Russian) [Брагин C.C. Использование палеомагнитных данных для решения некоторых вопросов геологии позднего рифея Присаянья // Стратиграфия позднего докембрия и раннего палеозоя Сибири: венд и рифей / Ред. В.В. Хоментовский. Новосибирск: ИГиГ СО АН СССР, 1985. С. 57-64].

Condie K.C., 1993. Chemical composition and evolution of the upper continental crust: contrasting results from surface samples and shales. Chemical Geology 104 (1-4), 1-37. http://dx.doi.org/10.1016/0009-2541(93)90140-E.

Cullers R.L., 2002. Implications of elemental concentrations for provenance, redox conditions, and metamorphic studies of shales and limestones near Pueblo, CO, USA. Chemical Geology 191 (4), 305-327. http://dx.doi.org/10.1016/ S0009-2541(02)00133-X.

Decisions of the All-Union Stratigraphic Meeting on Precambrian, Paleozoic and Quaternary System of Central Siberia. Part 1. Novosibirsk, 1983. 214 p. (in Russian) [Решения всесоюзного стратиграфического совещания по докембрию, палеозою и четвертичной системе Средней Сибири. Ч. 1. Новосибирск, 1983. 214 с.].

Dickinson W.R., Beard L.S., Brackenridge G.R., Erjavec J.L., Ferguson R.C., Inman K.F., Knepp R.A., Lindberg F.A., Ryberg P.T., 1983. Provenance of North American Phanerozoic sandstones in relation to tectonic setting. Geological Society of America Bulletin 94 (2), 222-235. http://dx.doi.org/10.1130/0016-7606(1983)94<222:PONAPS>2.0.C0;2.

Dolnik T.A., 2000. Stromatolites and Microphytolites in Stratigraphy of the Riphean and Vendian Folded Frame of the Southern Part of the Siberian Platform. GEO Publishing House of SB RAS, Novosibirsk, 320 p. (in Russian) [Дольник T.A. Строматолиты и микрофитолиты в стратиграфии рифея и венда складчатого обрамления юга Сибирской платформы. Новосибирск: Изд-во СО РАН, филиал «Гео», 2000. 320 с.].

Dolnik T.A., Vorontsov G.A., 1972. New data on the age of sediments of the Karagass series in Prisayanie. Doklady AN SSSR 204 (2), 426-429 (in Russian) [Дольник T.A., Воронцова Г.А. Новые данные о возрасте отложений карагасской серии Присаянья // Доклады АН СССР. 1972. Т. 204. № 2. С. 426-429].

Donskaya T.V., Gladkochub D.P., Mazukabzov A.M., Motova Z.L., Lvov P.A., 2016. The new Early Proterozoic SayanoBiryusa volcano-plutonic belt in the southern part of the Siberian craton. In: Geodynamic evolution of the lithosphere of the Central Asian mobile belt (from ocean to continent). Issue 14. IEC SB RAS, Irkutsk, p. 82-84 (in Russian) [Донская Т.В., Гладкочуб Д.П., Мазукабзов А.М., Мотова З.Л., Львов П.А. Новый Саяно-Бирюсинский раннепротерозойский вулканоплутонический пояс в южной части Сибирского кратона // Геодинамическая эволюция литосферы Центрально-Азиатского подвижного пояса (от океана к континенту). Вып. 14. Иркутск: ИЗК СО РАН, 2016. С. 82-84].

Donskaya T.V., Gladkochub D.P., Mazukabzov A.M., Wingate M.T.D., 2014. Early Proterozoic postcollisional granitoids of the Biryusa block of the Siberian craton. Russian Geology and Geophysics 55 (7), 812-823. http://dx.doi.org/ 10.1016/j.rgg.2014.06.002.

Fedo C.M., Nesbitt H.W., Young G.M., 1995. Unraveling the effects of potassium metasomatism in sedimentary rocks and paleosols, with implications for paleoweathering conditions and provenance. Geology 23 (10), 921-924. http:// dx.doi.org/10.1130/0091-7613(1995)023<0921:UTEOPM>2.3.CO;2.

Galimova T.F., Pashkov A.G., Povarintseva S.A., Perfil'ev V.V., Namolova M.M., Andryushchenko S.V., Denisenko E.P., Permyakov S.A., 2011. The State Geological Map of the Russian Federation. Scale 1: 1000000 (Series 3). AngaraYenisei Series. Sheet N-47 - Nizhneudinsk. VSEGEI Cartographic Factory, St. Petersburg, 301 p. (in Russian) $[\Gamma a-$ лимова Т.Ф., Пашкова А.Г., Поваринцева С.А., Перфильев В.В., Намолова М.М., Андрющенко С.В., Денисенко Е.П., Пермяков С.A. Государственная геологическая карта Российской Федерации. Масштаб 1:1000000 (третье поколение). Серия Ангаро-Енисейская. Лист N-47 - Нижнеудинск. СПб.: Картографическая фабрика ВСЕГЕИ, 2011. 301 с.].

Khomentovskii V.V., 2002. Baikalian in Siberia. Geologiya i Geofizika (Russian Geology and Geophysics) 43 (4), 313-333.

Kopeliovich A.V., 1965. Epigenesis of Ancient Rock Beds of the Southwestern Russian Platform. Nauka, Moscow, 312 p. (in Russian) [Копелиович А.В. Эпигенез древних толщ юго-запада Русской платформы. М.: Наука, 1965. 312 с.]. 
Letnikova E.F., Kuznetsov A.B., Vishnevskaya I.A., Veshcheva S.V., Proshenkin A.I., Geng H., 2013. The Vendian passive continental margin in the southern Siberian Craton: geochemical and isotopic ( $\mathrm{Sr}, \mathrm{Sm}-\mathrm{Nd}$ ) evidence and $\mathrm{U}-\mathrm{Pb}$ dating of detrital zircons by the LA-ICP-MS method. Russian Geology and Geophysics 54 (10), 1177-1194. http:// dx.doi.org/10.1016/j.rgg.2013.09.004.

Levitskii V.I., Mel'nikov A.I., Reznitskii L.Z., Bibikova E.V., Kirnozova T.I., Kozakov I.K., Makarov V.A., Plotkina Yu.V., 2002. Early Proterozoic postcollisional granitoids in Southwestern Siberian craton. Geologiya i Geofizika (Russian Geology and Geophysics) 43 (8), 717-731.

Logvinenko N.V., 1974. Petrography of Sedimentary Rocks. Vysshaya Shkola, Moscow, 400 p. (in Russian) [Логвиненко H.B. Петрография осадочных пород. М.: Высшая школа, 1974. 400 с.].

McLennan S.M., 2001. Relationships between the trace element composition of sedimentary rocks and upper continental crust. Geochemistry, Geophysics, Geosystems 2 (4), 1021. http://dx.doi.org/10.1029/2000GC000109.

McLennan S.M., Hemming S., McDaniel D.K., Hanson G.N., 1993. Geochemical approaches to sedimentation, provenance, and tectonics. In: M.J. Johnsson, A. Basu (Eds.), Processes controlling the composition of clastic sediments. Geological Society of America Special Papers, vol. 284, p. 21-40. http://dx.doi.org/10.1130/SPE284-p21.

Metelkin D.V., Blagovidov V.V., Kazansky A.Y., 2010. The history of the Karagas Supergroup evolution in the Biryusa region: synthesis of paleomagnetic and sedimentological data. Russian Geology and Geophysics 51 (8), 868-884. http://dx.doi.org/10.1016/j.rgg.2010.07.005.

Motova Z.L., 2016. Ages of detrital zircons in the Late Precambrian sedimentary beds of the south-western flank of the Siberian craton and their geodynamic interpretation. In: Scientific conference of young scientists and postgraduate students, IPE RAS. Abstracts, and conference programme (Moscow, April 25-26, 2016). IPE RAS, Moscow, p. 46 (in Russian) [Мотова 3.Л. Возрасты детритовых цирконов в позднедокембрийских осадочных толщах юго-западного фланга Сибирского кратона и их геодинамическая интерпретация // Научная конференция молодых ученых и аспирантов ИФЗ РАН: Тезисы докладов и программа конференции (г. Москва, 25-26 апреля 2016 г.). М.: ИФЗ РАН, 2016. С. 46].

Nesbitt H.W., Young G.M., 1982. Early Proterozoic climates and plate motions inferred from major element chemistry of lutites. Nature 299 (5885), 715-717. http://dx.doi.org/10.1038/299715a0.

Nesbitt H.W., Young G.M., 1989. Formation and diagenesis of weathering profiles. The Journal of Geology 97 (2), 129-147.

Nozhkin A.D., Gavrilenko V.A., 1976. Gold and radioactive elements in polyfacial deposits of the Upper Precambrian (cases of the Upper Riphean and Vendian northern Yenisei Ridge). Proceedings of the Institute of Geology and Geophysics. Issue 324. Nauka, Novosibirsk, 198 p. (in Russian) [Ножкин А.Д., Гавриленко В.А. Золото и радиоактивные элементы в полифациальных отложениях верхнего докембрия (на примере верхнего рифея и венда северной части Енисейского кряжа). Труды Института геологии и геофизики. Вып. 324. Новосибирск: Наука, 1976. 198 с.].

Nozhkin A.D., Turkina O.M., Sovetov Y.K., Travin A.V., 2007. The Vendian accretionary event in the southwestern margin of the Siberian Craton. Doklady Earth Sciences 415 (2), 869-873. http://dx.doi.org/10.1134/S1028334X0706 0098.

Panteeva S.V., Gladkochoub D.P., Donskaya T.V., Markova V.V., Sandimirova G.P., 2003. Determination of 24 trace elements in felsic rocks by inductively coupled plasma mass spectrometry after lithium metaborate fusion. Spectrochimica Acta Part B: Atomic Spectroscopy 58 (2), 341-350. http://dx.doi.org/10.1016/S0584-8547(02)00151-9.

Pettijohn F.J., 1975. Sedimentary Rocks (Third edition). Harper \& Row, New York, 628 p. [Русский перевод: Петтиджон Ф.Дж. Осадочные породы. М.: Недра, 1981. 751 с.].

Pettijohn F.J., Potter P.E., Siever R., 1972. Sand and Sand-stones. Springer, New York, 158 p.

Revenko A.G., 2014. Physical and chemical methods of researching rocks and minerals in the Analytical Centre of the Institute of the Earth's crust, SB RAS. Geodynamics \& Tectonophysics 5 (1), 101-114 (in Russian) [Ревенко А.Г. Физические и химические методы исследования горных пород и минералов в Аналитическом центре ИзК СО РАН // Геодинамика и тектонофизика. 2014. T. 5. № 1. С. 101-114]. http://dx.doi.org/10.5800/GT-2014-5-10119.

Rojas-Agramonte Y., Kröner A., Demoux A., Xia X., Wang W., Donskaya T., Liu D., Sun M., 2011. Detrital and xenocrystic zircon ages from Neoproterozoic to Palaeozoic arc terranes of Mongolia: significance for the origin of crustal fragments in the Central Asian Orogenic Belt. Gondwana Research 19 (3), 751-763. http://dx.doi.org/10.1016/j.gr. 2010.10.004.

Shenfil' V.Yu., 1991. Late Precambrian of the Siberian Platform. Nauka, Novosibirsk, 185 p. (in Russian) [Шенфиль В.Ю. Поздний докембрий Сибирской платформы. Новосибирск: Наука, 1991. 185 с.].

Sklyarov E.V. (Ed.), 2001. Interpretation of Geochemical Data. Intermet Engineering, Moscow, 288 p. (in Russian) [Интерпретация геохимических данных / Ред. Е.В. Скляров. М.: Интермет Инжиниринг, 2001. 288 с.].

Sklyarov E.V. (Ed.), 2006. Precambrian Evolution of Southern Part of the Siberian Craton. Siberian Branch of RAS Publishing House, Novosibirsk, 367 p. (in Russian) [Эволюция южной части Сибирского кратона в докембрии / Ред. Е.В. Скляров. Новосибирск: Изд-во СО РАН, 2006. 367 с.].

Sovetov Yи.K., 2011. Vendian sedimentary basin in the southwestern part of the Siberian craton: two stages of formation. In: Geodynamic evolution of the lithosphere of the Central Asian mobile belt (from ocean to continent). 
Issue 9. IEC SB RAS, Irkutsk, p. 190-192 (in Russian) [Советов Ю.К. Вендский осадочный бассейн на югозападе Сибирского кратона: два этапа формирования // Геодинамическая эволюция литосферы Центрально-Азиатского подвижного пояса (от океана к континенту): Вып. 9. Иркутск: ИЗК СО РАН, 2011. C. 190-192].

Sovetov Yu.K., Hoffman M., Kazak A.K., Solovetskaya L.V., 2015. Two areas of denudation and petrographic provinces with clastic material of Vendian sedimentary basins of the Siberian platform according to sedimentological and petrographic analysis and age of detrital zircons. In: Geodynamic evolution of the lithosphere of the Central Asian mobile belt (from ocean to continent). Issue 13. IEC SB RAS, Irkutsk, p. 227-229 (in Russian) [Советов Ю.К., Хо фман М., Казак А.К., Соловецкая Л.В. Две области сноса и петрографические провинции кластического материала вендских осадочных бассейнов Сибирской платформы по данным седиментологического и петрографического анализа и по возрасту детритовых цирконов // Геодинамическая эволюция литосферы Центрально-Азиатского подвижного пояса (от океана к континенту). Вып. 13. Иркутск: ИЗК СО РАН, 2015. C. 227-229].

Sovetov Yu.K., Komlev D.A., 2005. Tillites at the base of the Oselok Group, foothills of the Sayan Mountains, and the Vendian lower boundary in the southwestern Siberian Platform. Stratigraphy and Geological Correlation 13 (4), 337-366.

Stanevich A.M., Mazukabzov A.M., Postnikov A.A., Nemerov V.K., Pisarevsky S.A., Gladkochub D.P., Donskaya T.V., Kornilova T.A., 2007. Northern segment of the Paleoasian Ocean: Neoproterozoic deposition history and geodynamics. Russian Geology and Geophysics 48 (1), 46-60. http://dx.doi.org/10.1016/j.rgg.2006.12.005.

Taylor S.R., McLennan S.M., 1985. The Continental Crust: Its Composition and Evolution. Blackwell, London, $312 \mathrm{p}$. [Русский перевод: Тейлор С.P., Мак-Леннан С.М. Континентальная кора: ее состав и эволюция. М.: Мир, 1988. 384 c.].

Turkina O.M., Bibikova E.V., Nozhkin A.D., 2003. Stages and geodynamic settings of Early Proterozoic granite formation on the southwestern margin of the Siberian Craton. Doklady Earth Sciences 389 (2), 159-163.

Turkina O.M., Nozhkin A.D., Bayanova T.B., 2006. Sources and formation conditions of Early Proterozoic granitoids from the southwestern margin of the Siberian craton. Petrology 14 (3), 262-283. http://dx.doi.org/10.1134/ S0869591106030040.

Varga A.R., Szakmány G., 2004. Geochemistry and provenance of the upper carboniferous sandstones from Borehole Diósviszló-3 (Téseny Sandstone Formation, SW Hungary). Acta Mineralogica-Petrographica, Szeged 45 (2), 7-14.

Varga A., Szakmány G., Árgyelán T., Józsa S., Raucsik B., Máthé Z., 2007. Complex examination of the Upper Paleozoic siliciclastic rocks from southern Transdanubia, SW Hungary - Mineralogical, petrographic, and geochemical study. In: J. Arribas, M.J. Johnsson, S. Critelli (Eds.), Sedimentary Provenance and Petrogenesis: Perspectives from Petrography and Geochemistry. Geological Society of America Special Papers, vol. 420, p. 221-240. http://dx.doi.org/ 10.1130/2006.2420(14).

Yapaskurt O.V., 1994. Stage Analysis of Lithogenesis. MSU Publishing House, Moscow, 142 p. (in Russian] [Яnaскурm O.В. Стадиальный анализ литогенеза. М.: Изд-во МГУ, 1994. 142 с.].

Yudovich Ya.E., Ketris M.P., 2000. Fundamentals of Lithochemistry. Nauka, St. Petersburg, 497 p. (in Russian) [Юдович Я.Э., Кетрис М.П. Основы литохимии. СПб.: Наука, 2000. 497 с.].

Yudovich Ya.E., Ketris M.P., 2008. Mineral Indicators of Lithogenesis. Geoprint, Syktyvkar, 564 p. (in Russian) [Юдович Я.Э., Кетрис М.П. Минеральные индикаторы литогенеза. Сыктывкар: Геопринт, 2008. 564 с.

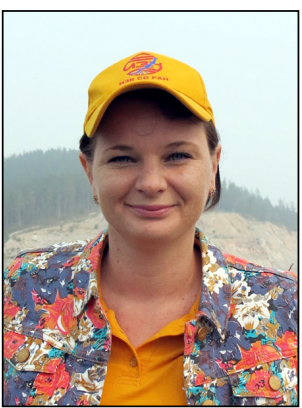

Мотова Зинаида Леонидовна, аспирант, м.н.с.

Институт земной коры СО РАН

664033, Иркутск, ул. Лермонтова, 128, Россия

Тел.: +79149017874; факс: (3952)427000; $\bowtie$ e-mail: motova@crust.irk.ru

Motova, Zinaida L., Post Graduate Student, Junior Researcher

Institute of the Earth's Crust, Siberian Branch of RAS

128 Lermontov street, Irkutsk 664033, Russia

Tel.: +79149017874; Fax: (3952)427000; $₫$ e-mail: motova@crust.irk.ru 


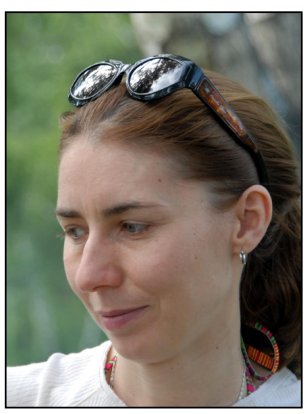

Донская Татьяна Владимировна, канд. геол.-мин. наук, в.н.с.

Институт земной коры СО РАН

664033, Иркутск, ул. Лермонтова, 128, Россия

e-mail: tanlen@crust.irk.ru

Donskaya, Tatiana V., Candidate of Geology and Mineralogy, Lead Researcher

Institute of the Earth's Crust, Siberian Branch of RAS

128 Lermontov street, Irkutsk 664033, Russia

e-mail: tanlen@crust.irk.ru

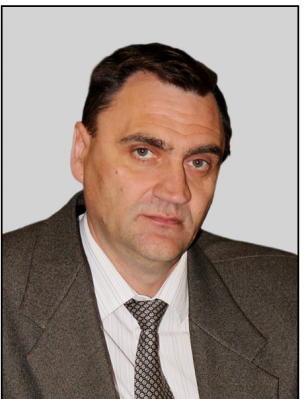

Гладкочуб Дмитрий Петрович, докт. геол.-мин. наук, член-корреспондент РАН, профессор РАН, директор института

Институт земной коры СО РАН

664033, Иркутск, ул. Лермонтова, 128, Россия

e-mail: dima@crust.irk.ru

Gladkochub, Dmitry P., Doctor of Geology and Mineralogy, Corresponding Member of RAS, Professor of RAS, Director of the Institute

Institute of the Earth's Crust, Siberian Branch of RAS

128 Lermontov street, Irkutsk 664033, Russia

e-mail: dima@crust.irk.ru 